\title{
ANALISIS PENILAIAN PROPERTI KOMERSIAL (Studi Kasus : Villatel dan Condotel X, Kabupaten Bogor)
}

\author{
Tegar Wibowo $^{1 凶}$, Ida Ayu Ari Anggreni ${ }^{2}$

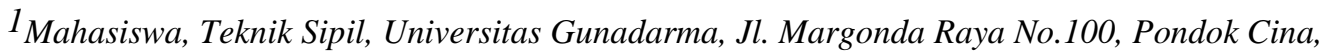 \\ Kecamatan Beji, Kota Depok, Jawa Barat 16424, \\ 2 Dosen, Teknik Sipil, Universitas Gunadarma, Jl. Margonda Raya No.100, Pondok Cina, \\ Kecamatan Beji, Kota Depok, Jawa Barat 16424, idaayu@staff.gunadarma.ac.id \\ $\otimes_{e-m a i l}$ :tegarw749@gmail.com
}

\begin{abstract}
The economic development of Indonesia from year to year, especially in terms of tourism developments and also the supporting factors that are Condotel, Villatel, and other lodging places. Given the promising business opportunity in terms of commercial properties in the field of tourism support, thus causing a large number of entrepreneurs who intend to build the commercial property, but before building a commercial property required the proper calculation and estimate of funds, the estimate of the market price and also the time period of sales estimates on the future commercial property will be sold, where the value of this market is also used by a Bank in determining the amount of funds that can be approved if there is a commercial On the basis of this research will examine the market value and the value of the liquidation of commercial properties, especially on the commercial properties of Villatel and Condotel using the method of income approach and cost approach. The results of research obtained after the thorough calculation of Condotel and Villatel obtained the market value of Rp. 145950000 000, while the value of liquidation or forced selling value of Rp. 102165000000 . The liquidation value is less than the market value due to the value of liquidation is $70 \%$ of the nominal market value.
\end{abstract}

Keywords : Property valuation, cost approach, revenue approach, Market value and liquidation value

\begin{abstract}
Abstrak
Perkembangan ekonomi Indonesia dari tahun ke tahun mengalami peningkatan, khususnya dalam hal perkembangan pariwisata dan juga faktor pendukungnya yaitu tempat penginapan berupa Condotel, Villatel, dan juga tempat penginapan yang lainnya. Mengingat adanya peluang bisnis yang menjanjikan dalam hal properti komersial pada bidang penunjang pariwisata, sehingga menyebabkan banyaknya pengusaha yang berniat membangun properti komersial tersebut, tetapi sebelum membangun sebuah properti komersial dibutuhkan perhitungan dan perkiraan dana yang tepat, perkiraan harga pasar dan juga jangka waktu perkiraan penjualan pada properti komersial yang kedepannya akan dijual, dimana nilai pasar ini juga digunakan oleh suatu Bank dalam menentukan besaran dana yang bisa disetujui jika ada properti komersial yang dijadikan agunan. Atas dasar tersebut pada penelitian ini akan meneliti mengenai nilai pasar dan nilai likuidasi properti komersial khususnya pada properti komersial Villatel dan Condotel dengan menggunakan metode pendekatan pendapatan dan pendekatan biaya. Hasil penelitian yang didapat setelah dilakukan perhitungan secara menyeluruh pada Condotel dan Villatel didapatkan nilai pasar sebesar Rp. 145950000 000, sedangkan nilai likuidasi atau nilai jual paksa sebesar Rp. 102165 000 000. Nilai likuidasi lebih kecil dibandingkan dengan nilai pasar dikarenakan nilai likuidasi adalah $70 \%$ dari nominal nilai pasar.
\end{abstract}

Kata Kunci : Penilaian Properti, Pendekatan Biaya, Pendekatan Pendapatan, Nilai Pasar dan Nilai Likuidasi 


\section{Pendahuluan}

\subsection{Latar Belakang}

Kabupaten Bogor adalah sebuah daerah yang berada di Provinsi Jawa Barat yang memiliki pertumbuhan ekonomi dan pariwisata yang tidak kalah bagus dibandingkan dengan daerah-daerah lain yang berada pada Provinsi Jawa Barat. Pertumbuhan yang bisa dilihat secara jelas adalah pertumbuhan bangunan fisik berupa Perumahan-Perumahan, Villa dan juga Hotel berkualitas menengah yang sudah banyak dibangun di Kabupaten Bogor. [1]

Ketika pembangunan mulai dicanangkan maka bidang yang bisa membantu agar pembangunan tersebut berjalan cepat dan efektif adalah bidang penilaian properti, hal ini dikarenakan sebelum pemerintah ataupun pengusaha ingin membuat sebuah bangunan maka akan dinilai terlebih dahulu berapa uang yang harus diinvestasikan, berapa nilai tanah ataupun bangunan sekitar yang akan dibangun sebuah bangunan, berapa tahun kira-kira uang yang diinvestasikan akan kembali dan berapa keuntungan yang didapat dari investasi tersebut. Menurut standar penilaian indonesia dalam bab konsep dan prinsip penilaian nilai adalah konsep ekonomi yang merujuk kepada harga yang sangat mungkin disepakati pembeli dan penjual dari suatu barang dan atau jasa yang tersedia untuk dibeli.

\subsection{Tujuan Penulisan}

Tujuan penulisan Tugas Akhir antara lain sebagai berikut :

1. a. Menganalisis Nilai Pasar Condotel dan Villatel $X$ yang berada di Kabupaten Bogor.

2. b. Menganalisis kisaran dana yang dibutuhkan untuk membangun sebuah Condotel dan Villatel yang berada di Kabupaten Bogor.

3. Menganalisis Nilai Likuidasi $\mathrm{X}$ yang berada di Kabupaten Bogor.

\subsection{Lokasi Perencanaan}

Pada penelitian ini, peneliti menilai salah satu properti yaitu $X$ yang berupa Condotel, Villatel dan Apartemen yang terletak di Kabupaten Bogor, Provinsi Jawa Barat.

\section{Tinjauan Pustaka}

\subsection{Penilaian Properti}

Penilai atau appraiser merupakan proses pekerjaan atau kegiatan seorang appraiser dalam memberikan suatu estimasi atau perkiraan nilai ekonomis suatu properti, berdasarkan hasil analisis terhadap fakta-fakta objektif dan relevan dengan menggunakan metode, parameter, dan prinsip-prinsip penilaian yang berlaku. penilaian properti adalah suatu proses pembentukan opini nilai pasar berdasarkan asumsi-asumsi tertentu. [2] Usaha jasa penilai publik ini merupakan usaha jasa profesional untuk memberikan penilaian yang obyektif dan independen terhadap aset atau properti. Usaha jasa ini diperlukan untuk membantu bank dalam melakukan penilaian suatu properti dan bisnis.

\subsection{Pengertian Harga, Biaya dan Nilai}

Istilah harga, biaya dan nilai dalam kehidupan sehari-hari seringkali digunakan secara kurang tepat. Menurut ilmu ekonomi, istilah harga menunjukkan suatu fakta yang dapat dicapai dalam penjualan atau transaksi. Harga adalah sejumlah uang yang disetujui pembeli untuk dibayarkan dan disetujui oleh penjual untuk diterima disaat tertentu dan melalui melalui mekanisme pasar yang wajar. [3] Menurut harga merupakan harga pertukaran aktual yang dapat diamati dipasar terbuka. Ketika terjadi transaksi (baik diungkapkan maupun tidak), maka harga menjadi suatu transaksi mencerminkan kondisi didalam satu atau beberapa pasar. Dalam hal lain, pasar 
merupakan satu perangkat pengaturan dimana pembeli dan penjual bersama-sama dipertemukan melalui mekanisme harga

\subsubsection{Teori Nilai Jual Paksa}

Nilai jual paksa disebut juga dengan likuidasi. Nilai likuidasi adalah sejumlah uang yang mungkin diterima dari penjualan suatu properti dalam jangka waktu yang relatif pendek untuk memenuhi jangka waktu pemasaran dalam definisi nilai pasar. Pada beberapa situasi, nilai jual paksa dapat melibatkan penjual yang tidak berminat menjual dan pembeli yang membeli dengan memenuhi situasi yang tidak menguntungkan penjual. Nilai jual paksa hanya dapat diberikan apabila terjadi kredit macet atau gagal bayar pembayaran (wanprestasi). [4]

\subsubsection{Faktor yang Mempengaruhi Nilai}

Ada banyak faktor yang mempengaruhi nilai suatu properti. Faktor tersebut akan berbeda satu sama lain pada setiap properti dan setiap penjual atau pembeli. Faktor-faktor tersebut juga akan berubah sesuai dengan perubahan waktu dan karakteristik pasar.

\subsubsection{Pengertian Aset, Properti, dan Condotel}

Menurut Siregar pengertian aset secara umum adalah barang (thing) atau sesuatu barang (anything) yang mempunyai nilai ekonomi (economic value), nilai komersial (commercial value) atau nilai tukar (exchange value) yang dimiliki oleh badan usaha, instansi atau individu (perseorangan). Dalam bidang akuntansi, aset berarti hak-hak dan kekayaan yang merupakan sumber penghasilan, sumber-sumber ekonomis yang diharapkan dapat memberikan hasil menguntungkan pada masa sekarang dan masa yang akan datang. [5]

\subsection{Alat Analisis}

Alat analisis adalah suatu cara ataupun pedoman berupa metoda dalam menilai sebuah properti dengan cara pendekatan yang biasa dilakukan oleh penilai dalam menilai sebuah bangunan, pendekatan tersebut sudah menjadi pegangan yang baku dimana dipakai secara menyeluruh oleh semua penilai yang berada di Indonesia, pendekatan tersebut memiliki beberapa macam, seperti :

\subsubsection{Pendekatan Biaya dengan Metoda Depreciated Replacement Cost}

Dalam penelitian properti dengan pendekatan biaya, elemen tanah dan bangunan dinilai dengan metoda yang berbeda. Tanah dinilai dengan metoda perbandingan penjualan, sedangkan bangunan dan sarana pelengkapnya dinilai dengan metoda Depreciated Replacement Cost (DRC) dimana biaya pembuatan baru (Reproduction Cost New/RCN) diestimasi berdasarkan standar harga yang berlaku pada saat penilaian dan selanjutnya dikurangi depresiasi atau penyusutan. Untuk menentukan indikasi nilai pasar tanah akan dijumlahkan dengan indikasi nilai pasar bangunan dan sarana pelengkapnya kemudian dikurangi dengan depresiasi (Depreciated Replacement Cost).

\subsubsection{Pendekatan pendapatan dengan metoda Discounted Cash Flow}

Nilai pasar properti berdasarkan pendekatan pendapatan merupakan nilai kini (present value) dari rangkaian pendapatan bersih tahunan Condotel selama tahun proyeksi ditambah dengan nilai kini (present value) dari terminal, dengan asumsi-asumsi tertentu. Discounted Cash Flow (DCF) adalah teknik pembuatan model keuangan yang didasarkan pada asumsi mengenai prospek pendapatan dan biaya atas suatu properti atau usaha. 


\subsection{Rekonsiliasi Nilai}

Rekonsiliasi nilai [6] merupakan proses pengambilan kesimpulan terhadap indikasi nilai yang dihasilkan dari pendekatan yang digunakan dalam proses penilaian,yaitu pendekatan biaya dan pendekatan pendapatan. Rekonsiliasi nilai dilakukan dalam dua tahap yaitu melakukan review atau mengkaji ulang data dan proses penilaian pada masing-masing teknik penilaian, kemudian mengkaji perbedaan-perbedaan indikasi nilai dari setiap pendekatan penilaian dikaitkan dengan tujuan penilaian. Pada tahap rekonsiliasi ini, penilaian mempertimbangkan semua faktor, kemudian membuat keputusan (judgement) kesimpulan nilai yang sesuai. Kegiatan rekonsiliasi nilai untuk mendapatkan nilai pasar dapat dilakukan dengan cara pembobotan, rata-rata, atau pemilihan. Berdasarkan peraturan Nomor VIII.C.4 tentang pedoman penilaian dan penyajian laporan penilaian properti di Pasar Modal oleh Badan Pegawas Pasar Modal dan Lembaga Keuangan, rekonsiliasi nilai dilakukan dengan metoda rata-rata terimbang (gross weighted weighted method).

\section{Metodologi Penelitian}

\subsection{Diagram Alur Perencanaan}

Berikut ini adalah [7] bagan alir dari penelitian yang akan dilakukan dalam penelitian penilaian properti :

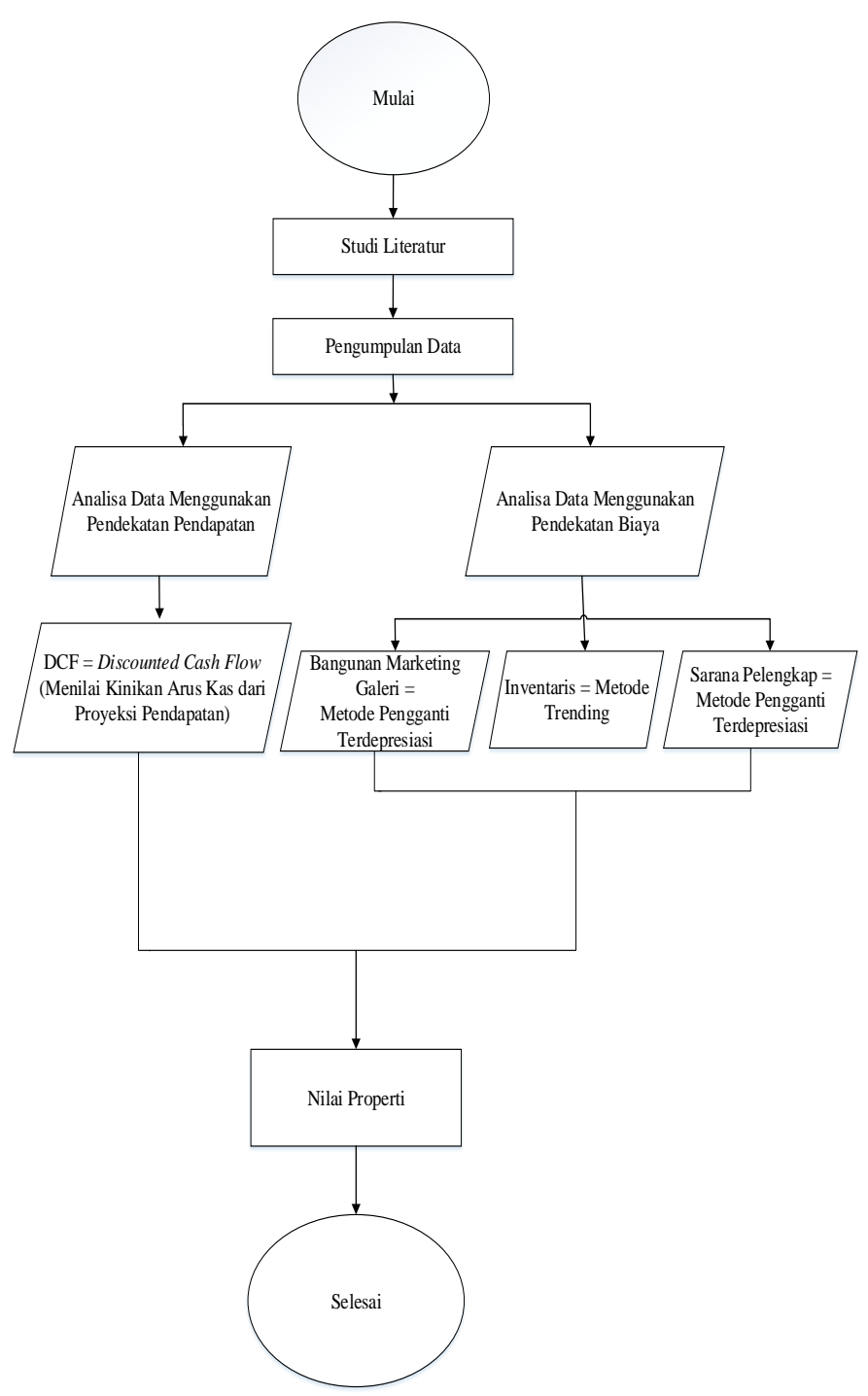

Gambar 1. Bagan Alur Penilaian

\section{Hasil Dan Pembahasan}

4.1 Analisis Makro Ekonomi

Pengertian makro ekonomi adalah studi tentang ekonomi secara keseluruhan atau bisa dianggap sebagai cakupan ilmu ekonomi yang luas. Makro ekonomi menjelaskan tentang perubahan ekonomi yang mempengaruhi banyak masyakarakat, perusahaan dan pasar.

\subsubsection{Pertumbuhan Ekonomi Jawa Barat \\ Perekonomian Jawa Barat menurut Badan Pusat Statistik Jawa Barat berdasarkan besaran Produk Domestik Regional Bruto (PDRB) atas dasar harga berlaku triwulan}


III-2019 mencapai Rp.544,56 triliun dan atas dasar harga konstan 2010 mencapai Rp.380,26 triliun. Ekonomi Jawa Barat triwulan III-2019 terhadap triwulan III-2018 tumbuh 5,14 persen (yoy) melambat dibanding capaian triwulan III-2018 sebesar 5,57 persen. Dari sisi produksi, pertumbuhan tertinggi dicapai oleh Lapangan Usaha Jasa Kesehatan dan Kegiatan Sosial sebesar 14,88 persen, dari sisi Pengeluaran dicapai oleh Komponen Pengeluaran Konsumsi Pemerintah yang tumbuh 9,80 persen. [1]

\subsubsection{Investasi}

Pengertian dari investasi menurut Kamus Besar Bahasa Indonesia adalah penanaman uang atau modal dalam suatu perusahaan atau proyek untuk tujuan memperoleh keuntungan. [8] Melihat dari faktor yang ada banyak faktor yang bisa mendukung bisnis Condotel dan Villatel di Kabupaten Bogor.

\subsubsection{Inflasi}

Pengertian dari inflasi menurut Kamus Besar Bahasa Indonesia adalah kemerosotan nilai uang (kertas) karena banyaknya dan cepatnya uang (kertas) beredar sehingga menyebabkan naiknya harga barang-barang. Provinsi Jawa Barat khususnya Kabupaten Bogor beberapa tahun terakhir memiliki catatan inflasi yang tidak terlalu tinggi dan masih dalam batas wajar sehingga tidak terlalu mengkhawatirkan untuk berbisnis dibidang properti [1].

\subsubsection{Suku Bunga}

Pengertian dari suku bunga menurut Wikipedia adalah imbal jasa atas pinjaman uang, Imbal jasa cipal. Persentase dari pokok utang yang dibayarkan sebagai imbal jasa (bunga) dalam suatu periode tertentu. Tingkat suku bunga dihitung berdasakan nilai rata-rata tertimbang dan disediakan hanya untuk kredit yang tidak diprioritaskan. Tingkat suku bunga pinjaman diklasifikaikan menurut jenis-jenis bank sebagai berikut : Bank Negara, Bank Pemerintah Daerah dan Bank yang lainnya.

\subsection{Perhitungan dan Analisis}

Penilaian Properti $\mathrm{X}$ berupa bangunan Condotel dan Villatel. Condotel yang dihitung adalah sisa Condotel yang belum terjual atau masih dalam kepemilikan PT.X, kasus yang sama juga berlaku pada Villatel, pada Properti ini penilaian membagi dalam 2 tahap, tahap 1 adalah pengembangan Condotel, Villatel, Marketing Gallery, Sarana Pelengkap dan Inventaris. Perhitungan Villatel dan Condotel dilakukan perhitungan dengan menggunakan pendekatan pendapatan (income approach), sedangkan dalam perhitungan Sarana Pelengkap dan Marketing Gallery menggunakan pendekatan biaya dan perhitungan Inventaris menggunakan pendekatan biaya (trending), lalu pada tahap 2 menghitung sisa Villatel yang belum terjual dengan menggunakan pendekatan pendapatan dengan metode land development analysis (LDA).

1. Perhitungan tahap satu

Tabel 1. Sisa Unit Stok

\begin{tabular}{llrrr}
\hline Condotel & Tipe & SG & \multicolumn{1}{c}{$\begin{array}{c}\text { Jumlah } \\
\text { Unit } \\
\text { Sisa }\end{array}$} & \multicolumn{1}{c}{$\begin{array}{l}\text { Total } \\
\text { Luas } \\
\text { (sqm) }\end{array}$} \\
\hline Studio & A1 & 35,87 & 13 & 466,31 \\
\cline { 2 - 5 } & A1-2 & 36,57 & 5 & 182,85 \\
\cline { 2 - 5 } & A2 & 50,40 & 2 & 100,80 \\
\hline & A3 & 54,24 & 2 & 108,48 \\
\hline & A4 & 65,45 & 4 & 261,80 \\
\hline \multirow{2}{*}{ BR } & A4-1 & 70,55 & 2 & 141,10 \\
\hline & B1 & 44,32 & 4 & 177,30 \\
\cline { 2 - 5 } & B3 & 49,65 & 6 & 297,90 \\
\hline \multirow{2}{*}{ 2 BR } & B6 & 70,43 & 2 & 140,86 \\
\cline { 2 - 5 } & B8 & 49,50 & 6 & 297,00 \\
\hline & C1 & 78,40 & 16 & $1.254,43$ \\
\hline & C2 & 59,18 & 2 & 118,36 \\
\hline
\end{tabular}


Tegar Wibowo, Ida Ayu Ari Anggreni, Analisis Penilaian...

\begin{tabular}{|c|c|c|c|c|}
\hline \multirow[t]{3}{*}{2 BR APT } & D1 & 73,38 & 5 & 366,91 \\
\hline & D2 & 71,75 & 4 & 286,99 \\
\hline & D2-2 & 71,75 & 2 & 143,50 \\
\hline \multirow{5}{*}{$\begin{array}{l}\text { Garden } \\
\text { Unit }\end{array}$} & E1 & 124,64 & 2 & 249,28 \\
\hline & E2 & 119,57 & 2 & 239,13 \\
\hline & E3 & 116,47 & 1 & 116,47 \\
\hline & E4 & 139,77 & 5 & 698,86 \\
\hline & E5 & 64,77 & 1 & 64,77 \\
\hline
\end{tabular}

Perhitungan Harga Pasar Condotel dengan Pembanding.

Data pembanding yang dipakai dalam menghitung Condotel ini adalah :

1. Aston Ciloto.

2. Alana Aston.

3. Aston Bogor Nirwana Residence.

Data pembanding tersebut dipakai karena mempunyai tingkat kemiripan dengan Condotel $\mathrm{X}$ ini (apple to apple) terdapat dalam Tabel 2.

Tabel 2. Market Positioning X

\begin{tabular}{|c|c|c|c|}
\hline Condotel & $\begin{array}{l}\text { Aston } \\
\text { Ciloto }\end{array}$ & $\begin{array}{l}\text { Alana } \\
\text { Aston }\end{array}$ & $\begin{array}{c}\text { Aston } \\
\text { Bogor } \\
\text { Nirwana } \\
\text { Residence }\end{array}$ \\
\hline Kategori & $1 \mathrm{BR}$ & $1 \mathrm{BR}$ & $1 \mathrm{BR}$ \\
\hline $\begin{array}{l}\text { Bangunan } \\
(s q m)\end{array}$ & 35 & 32 & 37 \\
\hline $\begin{array}{l}\text { Offering } \\
\text { Price } \\
\text { (Juta } \\
\text { Rupiah) }\end{array}$ & 1.400 & 1.300 & 1.350 \\
\hline $\begin{array}{l}\text { Diskon } \\
\text { (HC) }\end{array}$ & $15 \%$ & $15 \%$ & $15 \%$ \\
\hline $\begin{array}{l}\text { Nett Price } \\
\text { (Juta } \\
\text { Rupiah) }\end{array}$ & 1.190 & 1.105 & $1.147,5$ \\
\hline $\begin{array}{l}\text { Harga } \\
\text { Bangunan } \\
\text { per Meter } \\
\text { (Juta } \\
\text { Rupiah) }\end{array}$ & $33.864,542$ & $34.531,250$ & $31.013,514$ \\
\hline
\end{tabular}

Selanjutnya melakukan scoring terhadap data pembanding antara lain :

1. Lokasi.

2. Aksesibilitas.

3. Fasilitas.

4. Umur bangunan.

5. Desain interior.

6. Desain bangunan.
7. Ketinggian lantai.

8. Lot parkir.

Pada beberapa kriteria tersebut diberikan Nilai scoring dari angka yang paling kecil/jelek 1 sampai pada angka yang paling baik/bagus 5 pada Data Pembanding dan Aset, Perhitungan terdapat pada Tabel 3 dan Tabel 4 .

Tabel 3. Scoring Data Pembanding

\begin{tabular}{lcccc}
\hline Condotel & $\begin{array}{c}\text { Aston } \\
\text { Ciloto }\end{array}$ & $\begin{array}{c}\text { Alana } \\
\text { Aston }\end{array}$ & $\begin{array}{c}\text { Aston } \\
\text { Bogor } \\
\text { Nirwana }\end{array}$ & X \\
Residence & \\
\hline Location & 3,5 & 3,5 & 3,0 & 3,5 \\
\hline Access & 3,5 & 4,0 & 3,5 & 3,5 \\
\hline Facility & 3,5 & 3,5 & 3,0 & 3,5 \\
\hline $\begin{array}{l}\text { Age of } \\
\text { Building }\end{array}$ & 3,5 & 3,0 & 3,5 & 3,5 \\
\hline $\begin{array}{l}\text { Design } \\
\text { Interior }\end{array}$ & 3,0 & 3,5 & 3,0 & 3,0 \\
\hline $\begin{array}{l}\text { Design } \\
\text { Building }\end{array}$ & 3,0 & 3,5 & 3,0 & 3,0 \\
\hline $\begin{array}{l}\text { Floor } \\
\text { Count }\end{array}$ & 3,5 & 4,0 & 3,5 & 3,5 \\
\hline $\begin{array}{l}\text { Parking } \\
\text { Lot }\end{array}$ & 3,5 & 4,0 & 3,5 & 3,5 \\
\hline $\begin{array}{l}\text { Price } \\
\text { (Rp) }\end{array}$ & 33.864 .542 & 34.531 .250 & 31.013 .514 & 32.971 .546 \\
\hline & & & & \\
\hline
\end{tabular}

Tabel 4. Result of Market Positioning

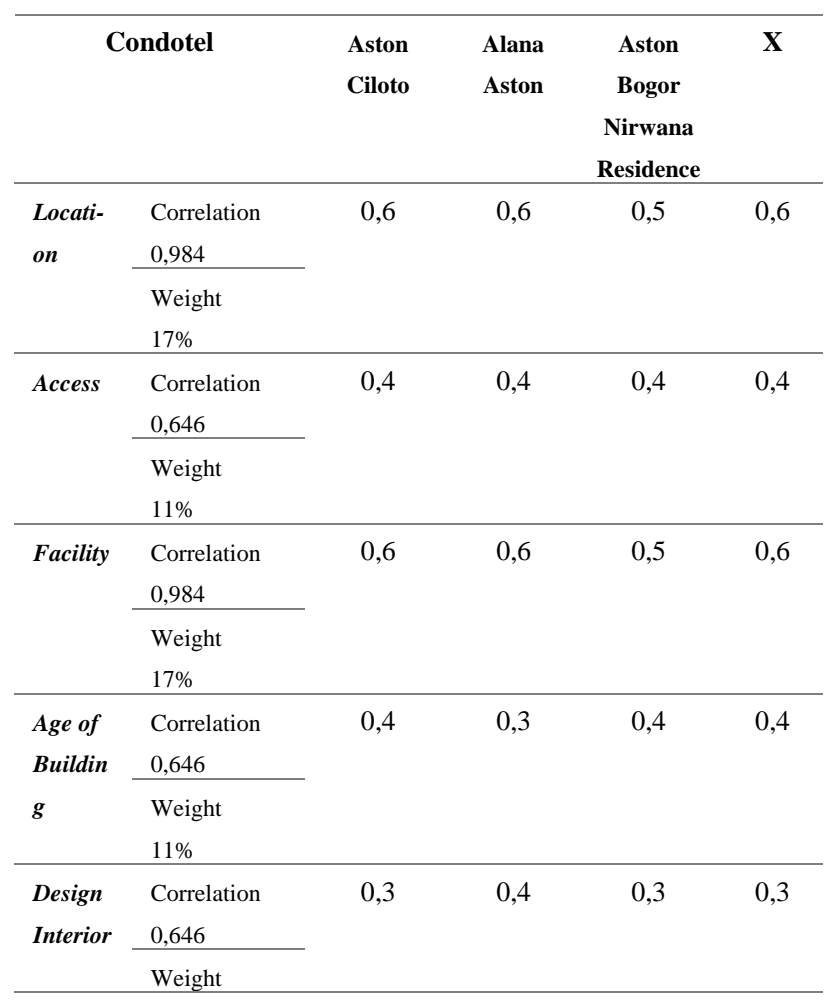


POLITEKNOLOGI VOL. 20 NO. 2 MEI 2021

\begin{tabular}{|c|c|c|c|c|c|c|c|c|c|c|}
\hline & $11 \%$ & & & & & & E5 & $64,77 \quad 34$. & 06.749 & $99.617 .432,96$ \\
\hline Design & Correlation & 0,3 & 0,4 & 0,3 & 0,3 & \multirow{6}{*}{\multicolumn{5}{|c|}{$\begin{array}{l}\text { Selanjutnya melakukan proyeksi } \\
\text { penjualan, seperti pada Tabel } 6 \text { didapat } \\
\text { dari Jumlah unit yang belum terjual } \\
\text { dikalikan dengan Semi Gross Area } \\
(S G A) \text {. }\end{array}$}} \\
\hline Buildin & 0,646 & & & & & & & & & \\
\hline$g$ & Weight $11 \%$ & & & & & & & & & \\
\hline \multirow{3}{*}{$\begin{array}{l}\text { Floor } \\
\text { Count }\end{array}$} & Correlation & \multirow[t]{3}{*}{0,4} & \multirow[t]{3}{*}{0,4} & \multirow[t]{3}{*}{0,4} & \multirow[t]{3}{*}{0,4} & & & & & \\
\hline & 0,646 & & & & & & & & & \\
\hline & Weight & & & & & & & & & \\
\hline \multirow{4}{*}{$\begin{array}{l}\text { Parkin } \\
\text { g Lot }\end{array}$} & Correlation & 0,4 & 0,4 & 0,4 & 0,4 & \multirow{2}{*}{\multicolumn{5}{|c|}{ Tabel 6. Proyeksi Penjualan }} \\
\hline & 0,646 & & & & & & & & & \\
\hline & Weight & & & & & \multirow[t]{3}{*}{ Condotel } & Tipe & SG & Jumlah & Total \\
\hline & $11 \%$ & & & & & & & & Unit & Luas \\
\hline \multirow{3}{*}{$\begin{array}{l}\text { Rate } \\
\text { Sale } \\
(\text { sqm })\end{array}$} & Correlation & \multirow[t]{3}{*}{3,4} & \multirow[t]{3}{*}{3,6} & \multirow[t]{3}{*}{3,2} & \multirow[t]{3}{*}{3,4} & & & & Sisa & $(s q m)$ \\
\hline & 5,847 & & & & & Studio & A1 & 35,87 & 13 & 466,31 \\
\hline & Weight $100 \%$ & & & & & & A1-2 & 36,57 & 5 & 182,85 \\
\hline \multirow{2}{*}{\multicolumn{2}{|c|}{ Point Estimate (BR) }} & \multirow[t]{2}{*}{9.991 .221} & 9.563 .93 & \multirow[t]{2}{*}{9.628 .115} & 9.727. & & A2 & 50,40 & 2 & 100,80 \\
\hline & & & 2 & & 756 & & $\mathrm{~A} 3$ & 54,24 & 2 & 108,48 \\
\hline \multicolumn{2}{|l|}{ Rating } & 3,39 & 3,61 & \multirow[t]{3}{*}{3,22} & \multirow[t]{3}{*}{3,39} & & A4 & 65,45 & 4 & 261,80 \\
\hline \multirow{2}{*}{\multicolumn{4}{|c|}{$\begin{array}{c}\text { Mean : 9.727.756 } \\
\text { Standar Deviasi : } 230.413\end{array}$}} & & & & A4-1 & 70,55 & 2 & 141,10 \\
\hline & & & & & & \multirow[t]{4}{*}{$1 \mathrm{BR}$} & B1 & 44,32 & 4 & 177,30 \\
\hline \multirow{4}{*}{\multicolumn{2}{|c|}{ Price per sqm }} & \multirow{2}{*}{\multicolumn{4}{|c|}{ Max : 33.752 .515}} & & B3 & 49,65 & 6 & 297,90 \\
\hline & & & & & & & B6 & 70,43 & 2 & 140,86 \\
\hline & & \multicolumn{4}{|c|}{ Average : 32.971 .546} & & B8 & 49,50 & 6 & 297,00 \\
\hline & & & Min $: 3$ & .190 .577 & & $2 \mathrm{BR}$ & $\mathrm{C} 1$ & 78,40 & 16 & $1.254,43$ \\
\hline & & & & & & & $\mathrm{C} 2$ & 59,18 & 2 & 118,36 \\
\hline Selan & utnya m & gnitun & rencar & & & 2 BR APT & D1 & 73,38 & 5 & 366,91 \\
\hline & & $\left(C^{4}\right)$ & 1 & & & & D2 & 71,75 & 4 & 286,99 \\
\hline Gros & Area & $S G A)$ & dengan & harga & & & D2-2 & 71,75 & 2 & 143,50 \\
\hline perm & er perse & Cond & el, per & nitungan & & Garden & E1 & 124,64 & 2 & 249,28 \\
\hline terda & at pada $\mathrm{T}$ & el 5 & & & & Unit & E2 & 119,57 & 2 & 239,13 \\
\hline & & & & & & & E3 & 116,47 & 1 & 116,47 \\
\hline & Tabel 5 & encana & arga Jual & & & & E4 & 139,77 & 5 & 698,86 \\
\hline & & & & & & & E5 & 64,77 & 1 & 64,77 \\
\hline & & SU & $\begin{array}{l}\text { leper } \\
\text { sqm }\end{array}$ & (Rupiah) & & Jun & ah Cond & & 86 & \\
\hline
\end{tabular}

Kemudian langkah selanjutnya adalah memproyeksikan rencana penjualan unit berdasarkan History kemampuan managemen dalam menjual setiap tahun.

Tabel 7. Proyeksi Rencana Penjualan Unit Condotel

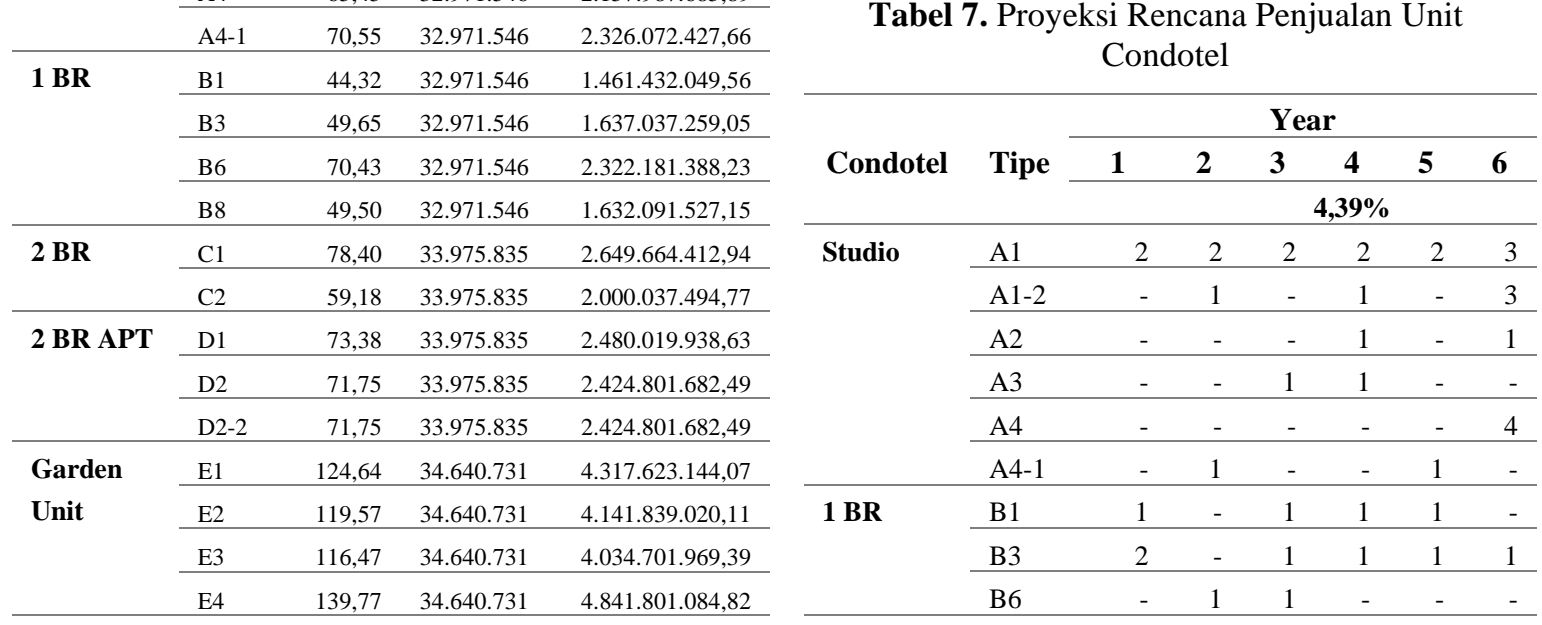

167 
Tegar Wibowo, Ida Ayu Ari Anggreni, Analisis Penilaian...

\begin{tabular}{|c|c|c|c|c|c|c|c|}
\hline & B8 & 2 & 2 & 1 & - & - & 1 \\
\hline \multirow[t]{2}{*}{2 BR } & $\mathrm{C} 1$ & 3 & 3 & 2 & 2 & 3 & 3 \\
\hline & $\mathrm{C} 2$ & - & - & - & 1 & 1 & - \\
\hline \multirow[t]{3}{*}{2 BR APT } & D1 & - & 1 & 1 & 1 & 1 & 1 \\
\hline & D2 & 1 & 1 & - & - & 1 & 1 \\
\hline & D2-2 & - & - & 1 & - & - & 1 \\
\hline \multirow{5}{*}{$\begin{array}{l}\text { Garden } \\
\text { Unit }\end{array}$} & E1 & - & - & 1 & - & 1 & - \\
\hline & E2 & - & - & - & 1 & - & 1 \\
\hline & E3 & - & - & - & - & 1 & - \\
\hline & E4 & - & - & - & 1 & - & 4 \\
\hline & E5 & - & - & - & - & 1 & - \\
\hline \multicolumn{2}{|c|}{ Jumlah Condotel } & 11 & 12 & 12 & 13 & 14 & 24 \\
\hline
\end{tabular}

Tabel 8. Proyeksi Luas SGA Rencana Penjualan

\begin{tabular}{|c|c|c|c|c|c|c|c|c|}
\hline \multirow{3}{*}{$\begin{array}{c}\text { Condo } \\
\text {-tel }\end{array}$} & \multirow{3}{*}{$\begin{array}{l}\text { Ti- } \\
\text { pe }\end{array}$} & \multirow{3}{*}{$\begin{array}{l}\text { Total } \\
\text { Luas } \\
(\text { sqm })\end{array}$} & \multicolumn{6}{|c|}{ Year } \\
\hline & & & 1 & 2 & 3 & 4 & 5 & 6 \\
\hline & & & & \multicolumn{5}{|c|}{$4,39 \%$} \\
\hline \multirow[t]{12}{*}{ Studio } & A1 & 466,31 & 71 & 71 , & 71 , & 71 & 71, & 107 \\
\hline & & & 74 & 74 & 74 & 74 & 74 &, 61 \\
\hline & $\mathrm{A} 1$ & 182,85 & - & 36 , & - & 36 , & - & 109 \\
\hline & -2 & & & 57 & & 57 & &, 71 \\
\hline & $\mathrm{A} 2$ & 100,80 & - & - & - & 50 & - & 50 , \\
\hline & & & & & & 40 & & 40 \\
\hline & A3 & 108,48 & - & - & 54 & 54 & - & - \\
\hline & & & & & 24 & 24 & & \\
\hline & A4 & 261,80 & - & - & - & - & - & 261 \\
\hline & & & & & & & & 80 \\
\hline & A4 & 141,10 & - & 70 , & - & - & 70 & - \\
\hline & -1 & & & 55 & & & 55 & \\
\hline \multirow[t]{8}{*}{$1 \mathrm{BR}$} & B1 & 177,30 & 44, & - & 44 , & 44 & 44 , & - \\
\hline & & & 32 & & 32 & 32 & 32 & \\
\hline & B3 & 297,90 & 99, & - & 49 , & 49, & 49 , & 49 , \\
\hline & & & 30 & & 65 & 65 & 65 & 65 \\
\hline & B6 & 140,86 & - & 70 , & 70 & - & - & - \\
\hline & & & & 43 & 43 & & & \\
\hline & B8 & 297,00 & 99, & 99 , & 49 , & - & - & 49 , \\
\hline & & & 00 & 00 & 50 & & & 50 \\
\hline \multirow[t]{4}{*}{$2 \mathrm{BR}$} & $\mathrm{C} 1$ & $1.254,43$ & 235 & 235 & 156 & 156 & 235 & 235 \\
\hline & & & ,21 &, 21 &, 80 &, 80 & ,21 &, 21 \\
\hline & $\mathrm{C} 2$ & 118,36 & - & - & - & 59, & 59 , & - \\
\hline & & & & & & 18 & 18 & \\
\hline \multirow{6}{*}{$\begin{array}{l}2 \mathrm{BR} \\
\mathrm{APT}\end{array}$} & D1 & 366,91 & - & 73 , & 73 & 73 & 73 & 73 , \\
\hline & & & & 38 & 38 & 38 & 38 & 38 \\
\hline & D2 & 286,99 & 71 , & 71 , & - & - & 71 , & 71 , \\
\hline & & & 75 & 75 & & & 75 & 75 \\
\hline & D2 & 143,50 & - & - & 71 , & - & - & 71 , \\
\hline & -2 & & & & 75 & & & 75 \\
\hline Garden & E1 & 249,28 & - & - & 124 & - & 124 & - \\
\hline \multirow[t]{7}{*}{ Unit } & & & & & ,64 & & ,64 & \\
\hline & E2 & 239,13 & - & - & - & 119 & - & 119 \\
\hline & & & & & &, 57 & &, 57 \\
\hline & E3 & 116,47 & - & - & - & - & 116 & - \\
\hline & & & & & & & ,47 & \\
\hline & $\mathrm{E} 4$ & 698,86 & - & - & - & 139 & - & 559 \\
\hline & & & & & & ,77 & & ,09 \\
\hline
\end{tabular}

\begin{tabular}{rrrrrrrrrr}
\hline E5 & 64,77 & - & - & - & - & 64, & - \\
& & & & & & 77 & \\
\hline & \multirow{2}{*}{$5.731,10$} & 621 & 728 & 766 & 855 & 981 & 1.759 \\
& &, 32 &, 62 &, 46 &, 63 &, 66 &, 41 \\
\hline
\end{tabular}

Tabel 9. Effective Gross Income (EGI) Proyeksi Penjualan Unit Condotel

\begin{tabular}{|c|c|c|c|c|c|c|c|}
\hline \multirow[t]{3}{*}{ Condotel } & \multirow[t]{3}{*}{ Tipe } & \multicolumn{6}{|c|}{ Year } \\
\hline & & \multirow[t]{2}{*}{1} & 2 & 3 & 4 & 5 & 6 \\
\hline & & & \multicolumn{5}{|c|}{$4,39 \%$} \\
\hline \multirow[t]{24}{*}{ Studio } & A1 & 2 & 2 & 2 & 2 & 2 & 4 \\
\hline & & .365 & .469 & .577 & .690 & .808 & .398 \\
\hline & & .378 & .218 & .617 & .774 & .899 & .316 \\
\hline & & .710 & .836 & .543 & .953 & .973 & .023 \\
\hline & A $1-2$ & - & 1 & - & 1 & - & 4 \\
\hline & & & .258 & & .371 & & .484 \\
\hline & & & .702 & & .642 & & .148 \\
\hline & & & .716 & & .599 & & .786 \\
\hline & A2 & - & - & - & 1 & - & 2 \\
\hline & & & & & .890 & & .059 \\
\hline & & & & & .368 & & .986 \\
\hline & & & & & .799 & & .317 \\
\hline & A3 & - & - & 1 & 2 & - & - \\
\hline & & & & .948 & .034 & & \\
\hline & & & & .842 & .396 & & \\
\hline & & & & .703 & .898 & & \\
\hline & A4 & - & - & - & - & - & 10 \\
\hline & & & & & & & .700 \\
\hline & & & & & & & .484 \\
\hline & & & & & & & .479 \\
\hline & A4-1 & - & 2 & - & - & 2 & - \\
\hline & & & .428 & & & .762 & \\
\hline & & & .187 & & & .223 & \\
\hline & & & .007 & & & .551 & \\
\hline \multirow[t]{16}{*}{$1 \mathrm{BR}$} & $\mathrm{B} 1$ & 1 & - & 1 & 1 & 1 & - \\
\hline & & .461 & & .592 & .662 & .735 & \\
\hline & & .432 & & .562 & .475 & .458 & \\
\hline & & .050 & & .270 & .754 & .439 & \\
\hline & B3 & 3 & - & 1 & 1 & 1 & 2 \\
\hline & & .274 & & .783 & .862 & .943 & .029 \\
\hline & & .074 & & .924 & .238 & .990 & .331 \\
\hline & & .518 & & .045 & .311 & .572 & .759 \\
\hline & B6 & - & 2 & 2 & - & - & - \\
\hline & & & .424 & .530 & & & \\
\hline & & & .125 & .544 & & & \\
\hline & & & .151 & .245 & & & \\
\hline & B8 & 3 & 3 & 1 & - & - & 2 \\
\hline & & .264 & .407 & .778 & & & .023 \\
\hline & & .183 & .480 & .534 & & & .200 \\
\hline & & .054 & .690 & .546 & & & .847 \\
\hline \multirow[t]{6}{*}{$2 \mathrm{BR}$} & $\mathrm{C} 1$ & 7 & 8 & 5 & 6 & 9 & 9 \\
\hline & & .948 & .297 & .774 & .028 & .439 & .853 \\
\hline & & .993 & .954 & .822 & .337 & .472 & .865 \\
\hline & & .239 & .042 & .816 & .538 & .334 & .169 \\
\hline & $\mathrm{C} 2$ & - & - & - & 2 & 2 & - \\
\hline & & & & & .275 & .375 & \\
\hline
\end{tabular}


POLITEKNOLOGI VOL. 20 NO. 2 MEI 2021

\begin{tabular}{|c|c|c|c|c|c|c|c|}
\hline & & & & & $\begin{array}{l}.175 \\
.122\end{array}$ & $\begin{array}{l}.055 \\
.310\end{array}$ & \\
\hline \multirow[t]{12}{*}{$2 \mathrm{BR}$ APT } & D1 & - & 2 & 2 & 2 & 2 & 3 \\
\hline & & & .588 & .702 & .821 & .945 & .074 \\
\hline & & & .892 & .545 & .186 & .037 & .324 \\
\hline & & & .814 & .208 & .943 & .050 & .176 \\
\hline & D2 & 2 & 2 & - & - & 2 & 3 \\
\hline & & .424 & .531 & & & .879 & .055 \\
\hline & & .801 & .250 & & & .465 & .873 \\
\hline & & 682 & .476 & & & .073 & .590 \\
\hline & D2-2 & - & - & 2 & - & - & 3 \\
\hline & & & & .642 & & & .055 \\
\hline & & & & .372 & & & .873 \\
\hline & & & & .372 & & & .590 \\
\hline Garden & E1 & - & - & 4 & - & 5 & - \\
\hline \multirow[t]{19}{*}{ Unit } & & & & .705 & & .127 & \\
\hline & & & & .031 & & .200 & \\
\hline & & & & .423 & & .765 & \\
\hline & E2 & - & - & - & 4 & - & 5 \\
\hline & & & & & .711 & & .134 \\
\hline & & & & & .616 & & .376 \\
\hline & & & & & .218 & & .396 \\
\hline & E3 & - & - & - & - & 4 & - \\
\hline & & & & & & .791 & \\
\hline & & & & & & .230 & \\
\hline & & & & & & .345 & \\
\hline & E4 & - & - & - & 5 & - & 24 \\
\hline & & & & & .507 & & .008 \\
\hline & & & & & .869 & & .300 \\
\hline & & & & & .428 & & .741 \\
\hline & E5 & - & - & - & - & 2 & - \\
\hline & & & & & & .730 & \\
\hline & & & & & & .808 & \\
\hline & & & & & & .102 & \\
\hline
\end{tabular}

Tabel 10. Sisa Unit Villa PT. $X$

\begin{tabular}{|c|c|c|c|c|}
\hline Villatel & $\begin{array}{c}\mathbf{L T} \\
(\mathrm{sqm})\end{array}$ & $\begin{array}{c}\text { LB } \\
(s q m)\end{array}$ & $\begin{array}{c}\text { Original } \\
\text { Stock } \\
\text { (Unit) }\end{array}$ & $\begin{array}{l}\text { Total } \\
\text { Luas } \\
(s q m)\end{array}$ \\
\hline Villa 1 & 186,55 & 230,00 & - & - \\
\hline Villa 2 & 195,10 & 208,00 & 1 & 208,00 \\
\hline Villa 3 & 172,05 & 212,00 & 1 & 212,00 \\
\hline Villa 4 & 203,50 & 215,00 & - & - \\
\hline \multicolumn{3}{|c|}{ Jumlah Villatel } & 2 & 420,00 \\
\hline
\end{tabular}

Tabel 11. Rencana Penjualan Villa

\begin{tabular}{lccc}
\hline Villatel & $\begin{array}{c}\text { LT } \\
(\text { sqm })\end{array}$ & $\begin{array}{c}\text { LB } \\
(\mathbf{s q m})\end{array}$ & $\begin{array}{c}\text { Price per Unit } \\
(\mathbf{R p})\end{array}$ \\
\hline Villa 1 & 186,55 & 230,00 & $3.465 .065 .732,10$ \\
\hline Villa 2 & 195,10 & 208,00 & $3.594 .266 .268,20$ \\
\hline Villa 3 & 172,05 & 212,00 & $3.366 .212 .893,10$ \\
\hline Villa 4 & 203,50 & 215,00 & $3.730 .019 .746,00$ \\
\hline
\end{tabular}

Tabel 12. Rencana Kenaikan Harga Jual Villa

\begin{tabular}{lrrrrrrr}
\hline & Price & \multicolumn{6}{c}{ Year } \\
\cline { 3 - 8 } Villatel & $\begin{array}{c}\text { per } \\
\text { Unit }\end{array}$ & $\mathbf{1}$ & $\mathbf{2}$ & $\mathbf{3}$ & $\mathbf{4}$ & $\mathbf{5}$ & $\mathbf{6}$ \\
\cline { 3 - 8 } & (Rp) & & \multicolumn{5}{c}{$\mathbf{4 , 3 9 \%}$} \\
\hline Villa 1 & 3 & 3 & 3 & 3 & 3 & 4 & 4 \\
& .465 & .465 & .617 & .775 & .941 & .114 & .295 \\
& .065 & .065 & .182 & .976 & .741 & .784 & .423 \\
& $.732,10$ & .732 & .118 & .413 & .777 & .241 & .269 \\
\hline Villa 2 & 3 & 3 & 3 & 3 & 4 & 4 & 4 \\
& .594 & .594 & .752 & .916 & .088 & .268 & .455 \\
& .266 & .266 & .054 & .769 & .715 & .210 & .585 \\
& $.268,20$ & .268 & .557 & .752 & .945 & .575 & .019 \\
\hline Villa 3 & 3 & 3 & 3 & 3 & 3 & 3 & 4 \\
& .366 & .366 & .513 & .668 & .829 & .997 & .172 \\
& .212 & .212 & .989 & .253 & .290 & .395 & .881 \\
& $.893,10$ & .893 & .639 & .784 & .125 & .962 & .645 \\
\hline Villa 4 & 3 & 3 & 3 & 4 & 4 & 4 & 4 \\
& .730 & .730 & .893 & .064 & .243 & .429 & .623 \\
& .019 & .019 & .767 & .704 & .144 & .418 & .870 \\
& $.746,00$ & .746 & .613 & .011 & .517 & .561 & .036 \\
\hline
\end{tabular}

Tabel 13. Rencana Proyeksi Penjualan Villa

\begin{tabular}{|c|c|c|c|c|c|c|c|}
\hline \multirow[t]{3}{*}{ Villatel } & \multirow{3}{*}{$\begin{array}{c}\text { Price } \\
\text { per } \\
\text { Unit } \\
\left(\_\right)\end{array}$} & \multicolumn{6}{|c|}{ Year } \\
\hline & & 1 & 2 & 3 & 4 & 5 & 6 \\
\hline & & \multicolumn{6}{|c|}{$4,39 \%$} \\
\hline Villa 1 & - & - & - & - & - & - & - \\
\hline Villa 2 & 208,00 & - & 1 & - & - & - & - \\
\hline Villa 3 & 212,00 & - & - & 1 & - & - & - \\
\hline Villa 4 & - & - & - & - & - & - & - \\
\hline $\begin{array}{l}\text { Jumlah } \\
\text { Villatel } \\
\end{array}$ & 420,00 & - & 1 & 1 & - & - & - \\
\hline
\end{tabular}

Tabel 14. Rencana Proyeksi Penjualan Villa (SGA)

\begin{tabular}{|c|c|c|c|c|c|c|c|}
\hline \multirow{3}{*}{ Villatel } & \multirow{3}{*}{$\begin{array}{c}\text { Price } \\
\text { per } \\
\text { Unit } \\
\left(\_\right)\end{array}$} & \multicolumn{6}{|c|}{ Year } \\
\hline & & 1 & 2 & 3 & 4 & 5 & 6 \\
\hline & & \multicolumn{6}{|c|}{$4,39 \%$} \\
\hline Villa 1 & - & - & - & - & - & - & - \\
\hline Villa 2 & 208,00 & - & $\begin{array}{r}208 \\
, 00\end{array}$ & - & - & - & - \\
\hline Villa 3 & 212,00 & - & - & $\begin{array}{r}212 \\
, 00\end{array}$ & - & - & - \\
\hline
\end{tabular}

Villa 4 
Tegar Wibowo, Ida Ayu Ari Anggreni, Analisis Penilaian...

Tabel 15. Rencana Proyeksi Penjualan Villa (SGA) dan Condotel

\begin{tabular}{|c|c|c|c|c|c|c|}
\hline \multirow{3}{*}{ Villatel } & \multicolumn{6}{|c|}{ Year } \\
\hline & 1 & 2 & 3 & 4 & 5 & 6 \\
\hline & \multicolumn{6}{|c|}{$4,39 \%$} \\
\hline Villa 1 & - & - & - & - & - & - \\
\hline \multirow[t]{4}{*}{ Villa 2} & - & 3 & - & - & - & - \\
\hline & & .752 & & & & \\
\hline & & .054 & & & & \\
\hline & & .557 & & & & \\
\hline \multirow[t]{4}{*}{ Villa 3} & - & - & 3 & - & - & - \\
\hline & & & .668 & & & \\
\hline & & & .253 & & & \\
\hline & & & .784 & & & \\
\hline Villa 4 & - & - & - & - & - & - \\
\hline Total & 20 & 29 & 31 & 32 & 39 & 73 \\
\hline \multirow{3}{*}{$\begin{array}{l}\text { Pendapa- } \\
\tan (\mathrm{Rp})\end{array}$} & .738 & .157 & .705 & .856 & .538 & .778 \\
\hline & .863 & .866 & .050 & .082 & .841 & .081 \\
\hline & .255 & .292 & .959 & .565 & .518 & .878 \\
\hline
\end{tabular}

Tabel 16. Biaya Operasional Pembangunan dan Penjualan Unit Condotel dan Villa

\begin{tabular}{lrrrrrr}
\hline \multicolumn{1}{c}{ Biaya } & & & & & & \\
& & & & & & \\
\cline { 2 - 7 } Operasional & \multicolumn{1}{c}{$\mathbf{1}$} & \multicolumn{1}{c}{$\mathbf{3}$} & \multicolumn{1}{c}{$\mathbf{4}$} & \multicolumn{1}{c}{$\mathbf{6}$} \\
General, & 1 & 1 & 1 & 1 & 1 & 3 \\
Overhead \& & .036 & .457 & .585 & .642 & .976 & .688 \\
Adm & .943 & .893 & .252 & .804 & .942 & .904 \\
\hline Marketing Fee & .163 & .315 & .548 & .128 & .076 & .094 \\
\hline & 622 & 874 & 951 & 985 & 1 & 2 \\
& .165 & .735 & .151 & .682 & .186 & .213 \\
& .898 & .989 & .529 & .477 & .165 & .342 \\
& & & & & .246 & .456 \\
\hline Advertising & 311 & 437 & 475 & 492 & 592 & 1 \\
& .082 & .367 & .575 & .841 & .082 & .106 \\
& .949 & .994 & .764 & .238 & .623 & .671 \\
Biaya Sosial, & 10 & 14 & 15 & 16 & 19 & 36 \\
dll & .369 & .578 & .852 & .428 & .769 & .889 \\
& .432 & .933 & .525 & .041 & .421 & .041 \\
\hline Keuntungan & 3 & 4 & 4 & 4 & 5 & 11 \\
Pengembang & .110 & .373 & .755 & .928 & .930 & .066 \\
& .829 & .679 & .757 & .412 & .826 & .712 \\
& .488 & .944 & .644 & .385 & .228 & .282 \\
\hline Total & 5 & 7 & 7 & 8 & 9 & 18 \\
Pengeluaran & .091 & .158 & .783 & .066 & .706 & .112 \\
& .390 & .256 & .590 & .168 & .785 & .519 \\
& .930 & .177 & .013 & .274 & .598 & .107
\end{tabular}

\begin{tabular}{lrrrrrr}
\hline Pendapatan & 15 & 21 & 23 & 24 & 29 & 55 \\
Bersih & .647 & .999 & .921 & .789 & .832 & .665 \\
& .472 & .610 & .460 & .914 & .055 & .562 \\
& .325 & .115 & .946 & .291 & .920 & .771 \\
& & & & & & \\
\hline Tingkat & & & $11,90 \%$ & & \\
Diskonto & & & & & & \\
\hline Discount & 0,89 & 0,79 & 0,71 & 0,63 & 0,570 & 0,509 \\
Factor & 37 & 86 & 37 & 78 & 0 & 3 \\
\hline Nilai Kini & 13 & 17 & 17 & 15 & 17 & 28 \\
Properti & .983 & .569 & .072 & .810 & .002 & .352. \\
& .367 & .126 & .238 & .492 & .827 & 552 \\
& .960 & .576 & .959 & .566 & .677 & .723 \\
& & & & & & \\
\hline
\end{tabular}

\section{GDV Erlangga}

Tower

$(3,09 \%)$

Nillai Kini -

GDV

Pembulatan

Tabel 17. BTB MAPPI Kabupaten Bogor Tahun 2019

\begin{tabular}{|c|c|}
\hline Jenis : & Low Rise Building \\
\hline LB & $858 \mathrm{~m}^{2}$ \\
\hline Jumlah Lantai : & 3 lantai \\
\hline Indeks Jual Lantai : & 1,00 \\
\hline Provinsi : & J_JAWA_BARAT \\
\hline Kabupaten / Kota : & KAB. BOGOR \\
\hline $\begin{array}{l}\text { Indeks Kemahalan } \\
\text { Konstruksi : }\end{array}$ & 0,9384 \\
\hline Tahun Penilaian : & 2019 \\
\hline Total Biaya Langsung (A) : & 3.217 .086 \\
\hline $\begin{array}{l}\text { Total Biaya Langsung } \\
\text { Adjustment } \mathrm{IKK}(\mathrm{A}) \text { : }\end{array}$ & 3.018 .932 \\
\hline $\begin{array}{l}\text { Total Biaya Langsung } \\
\text { Adjusment Indeks Lantai (A) : }\end{array}$ & 3.018 .932 \\
\hline BRB Bangunan (Rp) : & 3.263 .362 .635 \\
\hline Depresiasi Bangunan (Rp) : & 326.336 .264 \\
\hline $\begin{array}{l}\text { BRB Bangunan Terdepresiasi } \\
\text { (Rp) : }\end{array}$ & 2.937.026.372 \\
\hline
\end{tabular}




\begin{tabular}{|lcc|}
\hline \multicolumn{1}{|c}{ Keterangan } & Jumlah $(\mathbf{R p )}$ & $\mathbf{R p} / \mathbf{m}^{2}$ \\
$\begin{array}{l}\text { Total BRB } \\
\text { Bangunan \& } \\
\text { Fasilitas }\end{array}$ & 3.452 .677 .000 & 4.022 .927 \\
Total & & \\
Terdepresiasi & 373.751 .000 & 435.480 \\
$\begin{array}{l}\text { Total BRB } \\
\text { Terdepresiasi }\end{array}$ & 3.078 .925 .000 & 3.587 .445 \\
$\begin{array}{l}\text { Total BRB } \\
\text { Terdepresiasi } \\
\text { (Dibulatkan) }\end{array}$ & 3.078 .925 .000 & 3.587 .445 \\
\hline
\end{tabular}

Tabel 18. Sisa Stok Unit Villatel Tahap 2

\begin{tabular}{|c|c|c|c|c|}
\hline $\begin{array}{c}\text { Villatel } \\
\text { Tahap } \\
2\end{array}$ & $\begin{array}{c}\mathbf{L T} \\
(\mathrm{sqm})\end{array}$ & LB $(s q m)$ & $\begin{array}{c}\text { Original } \\
\text { Stock } \\
\text { (Unit) }\end{array}$ & $\begin{array}{l}\text { Total } \\
\text { Luas } \\
(\text { sqm })\end{array}$ \\
\hline
\end{tabular}

\begin{tabular}{|c|c|c|c|c|}
\hline A1 & 110 & 115,67 & - & - \\
\hline $\mathrm{A} 2$ & 108 & $115,118,58$ & - & - \\
\hline $\mathrm{A} 3$ & 103 & 118,58 & 1 & 103,22 \\
\hline A5 & 105 & 118,58 & - & - \\
\hline A6 & 108 & 118,58 & 1 & 107,62 \\
\hline A7 & 106 & 118,58 & 1 & 105,89 \\
\hline A8 & 105 & 131,23 & - & - \\
\hline A9 & 120 & 131,23 & 1 & 120,00 \\
\hline $\mathrm{A} 10$ & 120 & 131,23 & 1 & 120,00 \\
\hline A11 & 120 & 131,23 & 1 & 120,00 \\
\hline $\mathrm{A} 12$ & 120 & 131,23 & 1 & 120,00 \\
\hline A15 & 120 & 131,23 & 1 & 120,00 \\
\hline A16 & 120 & 131,23 & 1 & 120,00 \\
\hline A17 & 120 & 131,23 & 1 & 120,00 \\
\hline B1 & 75 & 73,80 & 1 & 74,93 \\
\hline B2 & 82 & 73,80 & 1 & 81,84 \\
\hline B3 & 87 & 73,80 & 1 & 86,69 \\
\hline B5 & 131 & 124,07 & 1 & 131,15 \\
\hline B6 & 137 & 124,07 & 1 & 136,57 \\
\hline $\mathrm{C} 1$ & 109 & 73,80 & - & - \\
\hline $\mathrm{C} 2$ & 75 & 73,80 & 1 & 75,00 \\
\hline $\mathrm{C} 3$ & 75 & 73,80 & 1 & 75,00 \\
\hline $\mathrm{C} 5$ & 75 & 73,80 & 1 & 75,00 \\
\hline $\mathrm{C} 6$ & 75 & 73,80 & 1 & 75,00 \\
\hline $\mathrm{C} 7$ & 75 & 73,80 & - & - \\
\hline $\mathrm{C} 8$ & 75 & 73,80 & 1 & 75,00 \\
\hline $\mathrm{C} 9$ & 75 & 73,80 & - & - \\
\hline $\mathrm{C} 10$ & 80 & 118,58 & 1 & 179,78 \\
\hline $\mathrm{C} 11$ & 203 & 130,64 & 1 & 203,49 \\
\hline $\mathrm{C} 12$ & 123 & 131,23 & 1 & 123,19 \\
\hline $\mathrm{C} 15$ & 125 & 131,23 & 1 & 124,88 \\
\hline $\mathrm{C} 16$ & 156 & 130,63 & 1 & 156,33 \\
\hline $\mathrm{C} 17$ & 127 & 131,23 & 1 & 126,54 \\
\hline
\end{tabular}

\begin{tabular}{|c|c|c|c|c|}
\hline $\mathrm{C} 18$ & 127 & 131,23 & 1 & 127,05 \\
\hline C19 & 142 & 131,23 & 1 & 142,33 \\
\hline $\mathrm{C} 20$ & 148 & 131,23 & 1 & 148,36 \\
\hline $\mathrm{C} 21$ & 140 & 131,23 & - & - \\
\hline $\mathrm{C} 22$ & 126 & 131,23 & 1 & 126,27 \\
\hline $\mathrm{C} 23$ & 132 & 131,23 & 1 & 132,13 \\
\hline D1 & 149 & 130,63 & - & - \\
\hline D2 & 120 & 131,23 & 1 & 120,00 \\
\hline D3 & 120 & 131,23 & 1 & 120,00 \\
\hline D5 & 35 & 130,64 & 1 & 135,00 \\
\hline D6 & 135 & 130,64 & - & - \\
\hline D7 & 120 & 131,23 & 1 & 120,00 \\
\hline D8 & 120 & 131,23 & 1 & 120,00 \\
\hline D9 & 149 & 130,63 & 1 & 149,14 \\
\hline $\begin{array}{l}\text { Jumlah } \\
\text { Villatel }\end{array}$ & 5.510 & 5.411 & 37 & 4.397 \\
\hline
\end{tabular}

Tabel 19. Market Positioning X Villatel Tahap 2

\begin{tabular}{ll}
\hline Lokasi : & Kab. Bogor \\
\hline KK : & 1 \\
\hline BTB R. Mewah : & 6.880 .000 \\
\hline BTB R. Menengah : & 4.410 .000
\end{tabular}

\begin{tabular}{|c|c|c|c|}
\hline \multicolumn{4}{|c|}{ COMPARABLE DATA } \\
\hline Villa & $\begin{array}{c}\text { Vimala } \\
\text { Hills } \\
\text { (APG) }\end{array}$ & $\begin{array}{c}\text { The } \\
\text { Leave } \\
\text { Boutique } \\
\text { Resort } \\
\text { Ciawi } \\
\end{array}$ & $\begin{array}{c}\text { Bogor } \\
\text { Nirwana } \\
\text { Residence }\end{array}$ \\
\hline Kategori & $\begin{array}{r}2 \mathrm{BR}, 1 \\
\text { lantai }\end{array}$ & $\begin{array}{r}2 \mathrm{BR}, 2 \\
\text { lantai }\end{array}$ & $\begin{array}{r}3 \mathrm{BR}, 2 \\
\text { lantai }\end{array}$ \\
\hline $\begin{array}{l}\text { Tanah } \\
(s q m)\end{array}$ & 200 & 140 & 131 \\
\hline $\begin{array}{l}\text { Bangunan } \\
(s q m)\end{array}$ & 126 & 152 & 140 \\
\hline $\begin{array}{l}\text { Offering } \\
\text { Price }\end{array}$ & \multicolumn{2}{|c|}{3.200 .000 .0002 .800 .000 .000} & 2.700 .000 .000 \\
\hline $\begin{array}{l}\text { Diskon } \\
(\mathrm{HC})\end{array}$ & $15 \%$ & $15 \%$ & $15 \%$ \\
\hline $\begin{array}{l}\text { Nett } \\
\text { Price }\end{array}$ & \multicolumn{2}{|c|}{2.720 .000 .0002 .380 .000 .000} & 2.295 .000 .000 \\
\hline $\begin{array}{l}\text { Tanah per } \\
s q m\end{array}$ & 9.720 .000 & 11.024 .229 & 11.636 .947 \\
\hline & |verage: & .642 .258 & \\
\hline
\end{tabular}

Tabel 20. Scoring Data Pembanding Villatel Tahap 2

\begin{tabular}{lcccc}
\hline Villatel & $\begin{array}{c}\text { Vimala } \\
\text { Hills }\end{array}$ & $\begin{array}{c}\text { The } \\
\text { Leave } \\
\text { Boutique }\end{array}$ & $\begin{array}{c}\text { Bogor } \\
\text { Nirwana } \\
\text { Residence }\end{array}$ & $\mathbf{X}$ \\
\hline Location & 3,5 & 3,5 & 3,0 & 3,5 \\
\hline Access & 3,5 & 4,0 & 3,5 & 3,5 \\
\hline
\end{tabular}


Tegar Wibowo, Ida Ayu Ari Anggreni, Analisis Penilaian...

\begin{tabular}{lcccc}
\hline Facility & 3,5 & 3,5 & 3,0 & 3,5 \\
\hline Price & 9.265 .600 & 11.024 .229 & 11.636 .947 & 11.087 .782 \\
$(\boldsymbol{R} p)$ & & & & \\
\hline
\end{tabular}

Tabel 21. Result of Market Positioning X Villatel Tahap 2

\begin{tabular}{|c|c|c|c|c|c|}
\hline \multicolumn{2}{|c|}{ Villatel } & \multirow{2}{*}{$\begin{array}{c}\text { Vima } \\
\text { la } \\
\text { Hills }\end{array}$} & \multirow{2}{*}{$\begin{array}{c}\text { The } \\
\text { Leave } \\
\text { Boutiqu } \\
\text { e }\end{array}$} & \multirow{2}{*}{$\begin{array}{c}\text { Bogor } \\
\text { Nirwana } \\
\text { Residence }\end{array}$} & \multirow[t]{2}{*}{$\mathbf{X}$} \\
\hline & & & & & \\
\hline \multirow{4}{*}{$\begin{array}{l}\text { Locati- } \\
\text { on }\end{array}$} & Correlation & 1,5 & 1,5 & 1,3 & 1,5 \\
\hline & 0,700 & & & & \\
\hline & Weight & & & & \\
\hline & $42 \%$ & & & & \\
\hline \multirow[t]{4}{*}{ Access } & Correlation & 0,6 & 0,6 & 0,6 & 0,6 \\
\hline & 0,269 & & & & \\
\hline & Weight & & & & \\
\hline & $16 \%$ & & & & \\
\hline \multirow[t]{4}{*}{ Facility } & Correlation & 1,5 & 1,5 & 1,3 & 1,5 \\
\hline & 0,700 & & & & \\
\hline & Weight & & & & \\
\hline & $42 \%$ & & & & \\
\hline Rental & Correlation & 3,5 & 3,6 & 3,1 & 3,5 \\
\hline Rate & 1,668 & & & & \\
\hline per & Weight & & & & \\
\hline Sqm & $100 \%$ & & & & \\
\hline \multirow{2}{*}{\multicolumn{2}{|c|}{ Point Estimate (BR) }} & 2.647 . & 3.078 . & 3.777 .569 & 3.167 . \\
\hline & & 314 & 930 & & 938 \\
\hline \multicolumn{2}{|l|}{ Rating } & 3,50 & 3,58 & 3,08 & 3,50 \\
\hline \multicolumn{6}{|c|}{$\begin{array}{c}\text { Mean : 3.167.938 } \\
\text { Standar Deviasi : } 570 / 360\end{array}$} \\
\hline \multirow{3}{*}{\multicolumn{2}{|c|}{ Price per sqm }} & \multicolumn{4}{|c|}{ Max : 13.084 .042} \\
\hline & & \multicolumn{4}{|c|}{ Average : 11.087 .782} \\
\hline & & \multicolumn{4}{|c|}{ Min : 9.091 .522} \\
\hline
\end{tabular}

Tabel 22. Rencana Harga Jual Villatel Tahap 2

\begin{tabular}{|c|c|c|c|c|c|}
\hline Villatel & $\begin{array}{c}\mathbf{L T} \\
(\mathrm{sqm})\end{array}$ & $\begin{array}{c}\mathbf{L B} \\
(s q m)\end{array}$ & $\begin{array}{c}\text { Origin } \\
\quad \text { al } \\
\text { Stock } \\
\text { (Unit) }\end{array}$ & $\begin{array}{l}\text { Total } \\
\text { Luas } \\
(\text { sqm })\end{array}$ & $\begin{array}{c}\text { Renca } \\
\text { na } \\
\text { Harga } \\
\text { Jual }\end{array}$ \\
\hline $\mathrm{A} 1$ & 110,25 & 115,67 & - & - & $\begin{array}{r}2.116 .6 \\
22.461\end{array}$ \\
\hline A2 & 108,47 & 115,21 & - & - & $\begin{array}{r}2.093 .7 \\
06.369\end{array}$ \\
\hline A3 & 103,22 & 118,58 & 1 & 118,58 & $\begin{array}{r}2.058 .6 \\
81.113\end{array}$ \\
\hline A5 & 105,42 & 118,58 & - & - & $\begin{array}{r}2.083 .0 \\
74.234 \\
\end{array}$ \\
\hline A6 & 107,62 & 118,58 & 1 & 118,58 & $\begin{array}{r}2.107 .4 \\
67.354 \\
\end{array}$ \\
\hline A7 & 105,89 & 118,58 & 1 & 118,58 & $\begin{array}{r}2.088 .2 \\
85.491 \\
\end{array}$ \\
\hline A8 & 105,10 & 118,38 & - & - & $\begin{array}{r}2.079 .5 \\
26.144 \\
\end{array}$ \\
\hline A9 & 120,00 & 131,23 & 1 & 131,23 & 2.331 .7 \\
\hline
\end{tabular}

\begin{tabular}{|c|c|c|c|c|c|}
\hline & & & & & 66.095 \\
\hline A10 & 120,00 & 131,23 & 1 & 131,23 & $\begin{array}{r}2.331 .7 \\
66.095\end{array}$ \\
\hline A11 & 120,00 & 131,23 & 1 & 131,23 & $\begin{array}{r}2.331 .7 \\
66.095\end{array}$ \\
\hline A12 & 120,00 & 131,23 & 1 & 131,23 & $\begin{array}{r}2.331 .7 \\
66.095\end{array}$ \\
\hline A15 & 120,00 & 131,23 & 1 & 131,23 & $\begin{array}{r}2.331 .7 \\
66.095\end{array}$ \\
\hline A16 & 120,00 & 131,23 & 1 & 131,23 & $\begin{array}{r}2.331 .7 \\
66.095\end{array}$ \\
\hline A17 & 120,00 & 131,23 & 1 & 131,23 & $\begin{array}{r}2.331 .7 \\
66.095\end{array}$ \\
\hline B1 & 74,93 & 73,80 & 1 & 73,80 & $\begin{array}{r}1.436 .9 \\
83.281\end{array}$ \\
\hline B2 & 81,84 & 73,80 & 1 & 73,80 & $\begin{array}{r}1.513 .5 \\
99.281 \\
\end{array}$ \\
\hline B3 & 86,69 & 73,80 & 1 & 73,80 & $\begin{array}{r}1.567 .3 \\
75.597 \\
\end{array}$ \\
\hline B5 & 131,15 & 124,07 & 1 & 124,07 & $\begin{array}{r}2.406 .1 \\
54.705\end{array}$ \\
\hline B6 & 136,57 & 124,07 & 1 & 124,07 & $\begin{array}{r}2.466 .2 \\
50.483 \\
\end{array}$ \\
\hline $\mathrm{C} 1$ & 108,88 & 73,80 & - & - & $\begin{array}{r}1.813 .4 \\
13.479 \\
\end{array}$ \\
\hline $\mathrm{C} 2$ & 75,00 & 73,80 & 1 & 73,80 & $\begin{array}{r}1.437 .7 \\
59.425\end{array}$ \\
\hline $\mathrm{C} 3$ & 75,00 & 73,80 & 1 & 73,80 & $\begin{array}{r}1.437 .7 \\
59.425\end{array}$ \\
\hline C5 & 75,00 & 73,80 & 1 & 73,80 & $\begin{array}{r}1.437 .7 \\
59.425\end{array}$ \\
\hline C6 & 75,00 & 73,80 & 1 & 73,80 & $\begin{array}{r}1.437 .7 \\
59.425\end{array}$ \\
\hline $\mathrm{C} 7$ & 75,00 & 73,80 & - & - & $\begin{array}{r}1.437 .7 \\
59.425\end{array}$ \\
\hline $\mathrm{C} 8$ & 75,00 & 73,80 & 1 & 73,80 & $\begin{array}{r}1.437 .7 \\
59.425\end{array}$ \\
\hline C9 & 75,00 & 73,80 & - & - & $\begin{array}{r}1.437 .7 \\
59.425\end{array}$ \\
\hline $\mathrm{C} 10$ & 179,78 & 118,58 & 1 & 118,58 & $\begin{array}{r}2.907 .5 \\
61.703 \\
\end{array}$ \\
\hline $\mathrm{C} 11$ & 203,49 & 130,64 & 1 & 130,64 & $\begin{array}{r}3.253 .4 \\
60.214 \\
\end{array}$ \\
\hline $\mathrm{C} 12$ & 123,19 & 131,23 & 1 & 131,23 & $\begin{array}{r}2.367 .1 \\
36.120 \\
\end{array}$ \\
\hline C15 & 124,88 & 131,23 & 1 & 131,23 & $\begin{array}{r}2.385 .8 \\
74.471 \\
\end{array}$ \\
\hline C16 & 156,33 & 130,63 & 1 & 130,63 & $\begin{array}{r}2.730 .4 \\
91.615 \\
\end{array}$ \\
\hline $\mathrm{C} 17$ & 126,54 & 131,23 & 1 & 131,23 & $\begin{array}{r}2.404 .2 \\
80.190 \\
\end{array}$ \\
\hline $\mathrm{C} 18$ & 127,05 & 131,23 & 1 & 131,23 & $\begin{array}{r}2.409 .9 \\
34.958\end{array}$ \\
\hline C19 & 142,33 & 131,23 & 1 & 131,23 & $\begin{array}{r}2.579 .3 \\
56.267\end{array}$ \\
\hline $\mathrm{C} 20$ & 148,36 & 131,23 & 1 & 131,23 & 2.646 .2 \\
\hline
\end{tabular}


POLITEKNOLOGI VOL. 20 NO. 2 MEI 2021

\begin{tabular}{lcccrr}
\hline & & & & & 15.593 \\
\hline C21 & 140,43 & 131,23 & - & - & 2.558 .2 \\
& & & & & 89.482 \\
\hline C22 & 126,27 & 131,23 & 1 & 131,23 & 2.401 .2 \\
& & & & & 86.488 \\
\hline C23 & 132,13 & 131,23 & 1 & 131,23 & 2.466 .2 \\
& & & & & 60.891 \\
\hline D1 & 149,14 & 130,63 & - & - & 2.650 .7 \\
& & & & & 70.463 \\
\hline D2 & 120,00 & 131,23 & 1 & 131,23 & 2.331 .7 \\
& & & & & 66.095 \\
\hline D3 & 120,00 & 131,23 & 1 & 131,23 & 2.331 .7 \\
& & & & & 66.095 \\
\hline D5 & 135,00 & 130,64 & 1 & 130,64 & 2.494 .0 \\
& & & & & 58.025 \\
\hline D6 & 135,00 & 130,64 & - & - & 2.494 .0 \\
& & & & & 58.025 \\
\hline D7 & 120,00 & 131,23 & 1 & 131,23 & 2.331 .7 \\
& & & & & 66.095 \\
\hline D8 & 120,00 & 131,23 & 1 & 131,23 & 2.331 .7 \\
& & & & & 66.095 \\
\hline D9 & 149,14 & 130,63 & 1 & 130,64 & 2.650 .7 \\
& & & & & 70.463 \\
\hline & Jumlah Villatel & & 37 & 4.329 & \\
\hline & & & & &
\end{tabular}

\begin{tabular}{|c|c|c|c|c|c|c|}
\hline & & 6.09 & 0.62 & 8.96 & 8.72 & 8.50 \\
\hline & & 5 & 7 & 1 & 5 & 9 \\
\hline Villa 7 & 2.331 .7 & 2.33 & 2.43 & 2.54 & 2.65 & 2.46 \\
\hline & 66.095 & 1.76 & 4.13 & 0.98 & 2.53 & 9.44 \\
\hline & & 6.09 & 0.62 & 8.96 & 8.72 & 8.50 \\
\hline & & 5 & 7 & 1 & 5 & 9 \\
\hline Villa 8 & 2.331 .7 & 2.33 & 2.43 & 2.54 & 2.65 & 2.46 \\
\hline & 66.095 & 1.76 & 4.13 & 0.98 & 2.53 & 9.44 \\
\hline & & 6.09 & 0.62 & 8.96 & 8.72 & 8.50 \\
\hline & & 5 & 7 & 1 & 5 & 9 \\
\hline Villa 9 & 2.331 .7 & 2.33 & 2.43 & 2.54 & 2.65 & 2.46 \\
\hline & 66.095 & 1.76 & 4.13 & 0.98 & 2.53 & 9.44 \\
\hline & & 6.09 & 0.62 & 8.96 & 8.72 & 8.50 \\
\hline & & 5 & 7 & 1 & 5 & 9 \\
\hline Villa 10 & 2.331 .7 & 2.33 & 2.43 & 2.54 & 2.65 & 2.46 \\
\hline & 66.095 & 1.76 & 4.13 & 0.98 & 2.53 & 9.44 \\
\hline & & 6.09 & 0.62 & 8.96 & 8.72 & 8.50 \\
\hline & & 5 & 7 & 1 & 5 & 9 \\
\hline Villa 11 & 1.436 .9 & 1.43 & 1.50 & 1.56 & 1.63 & 1.70 \\
\hline & 83.281 & 6.98 & 0.06 & 5.91 & 4.66 & 6.42 \\
\hline & & 3.28 & 6.84 & 9.78 & 3.66 & 5.39 \\
\hline & & 1 & 7 & 1 & 0 & 4 \\
\hline Villa 12 & 1.513 .5 & 1.51 & 1.58 & 1.64 & 1.72 & 1.79 \\
\hline & 99.854 & 3.59 & 0.04 & 9.41 & 1.82 & 7.40 \\
\hline & & 9.85 & 6.88 & 0.94 & 0.08 & 7.98 \\
\hline & & 4 & 8 & 6 & 7 & 9 \\
\hline Villa 13 & 1.567 .3 & 1.56 & 1.63 & 1.70 & 1.78 & 1.86 \\
\hline & 75.597 & 7.37 & 6.18 & 8.01 & 2.99 & 1.26 \\
\hline & & 5.59 & 3.38 & 1.83 & 3.55 & 6.97 \\
\hline & & 7 & 6 & 6 & 6 & 3 \\
\hline Villa 14 & 2.406 .1 & 2.40 & 2.51 & 2.62 & 2.73 & 2.85 \\
\hline & 54.705 & 6.15 & 1.78 & 2.05 & 7.16 & 7.32 \\
\hline & & 4.70 & 4.89 & 2.25 & 0.34 & 1.68 \\
\hline & & 5 & 6 & 3 & 7 & 6 \\
\hline Villa 15 & 2.466 .2 & 2.46 & 2.57 & 2.68 & 2.80 & 2.92 \\
\hline & 50.483 & 6.25 & 4.51 & 7.54 & 5.52 & 8.68 \\
\hline & & 0.48 & 8.87 & 0.25 & 3.27 & 5.74 \\
\hline & & 3 & 9 & 8 & 5 & 7 \\
\hline Villa 16 & 1.437 .7 & 1.43 & 1.50 & 1.56 & 1.63 & 1.70 \\
\hline & 59.425 & 7.75 & 0.87 & 6.76 & 5.54 & 7.34 \\
\hline & & 9.42 & 7.06 & 5.56 & 6.57 & 7.07 \\
\hline & & 5 & 4 & 7 & 6 & 0 \\
\hline Villa 17 & 1.437 .7 & 1.43 & 1.50 & 1.56 & 1.63 & 1.70 \\
\hline & 59.425 & 7.75 & 0.87 & 6.76 & 5.54 & 7.34 \\
\hline & & 9.42 & 7.06 & 5.56 & 6.57 & 7.07 \\
\hline & & 5 & 4 & 7 & 6 & 0 \\
\hline Villa 18 & 1.437 .7 & 1.43 & 1.50 & 1.56 & 1.63 & 1.70 \\
\hline & 59.425 & 7.75 & 0.87 & 6.76 & 5.54 & 7.34 \\
\hline & & 9.42 & 7.06 & 5.56 & 6.57 & 7.07 \\
\hline & & 5 & 4 & 7 & 6 & 0 \\
\hline Villa 19 & 1.437 .7 & 1.43 & 1.50 & 1.56 & 1.63 & 1.70 \\
\hline & 59.425 & 7.75 & 0.87 & 6.76 & 5.54 & 7.34 \\
\hline & & 9.42 & 7.06 & 5.56 & 6.57 & 7.07 \\
\hline & & 5 & 4 & 7 & 6 & 0 \\
\hline Villa 20 & 1.437 .7 & 1.43 & 1.50 & 1.56 & 1.63 & 1.70 \\
\hline
\end{tabular}


Tegar Wibowo, Ida Ayu Ari Anggreni, Analisis Penilaian...

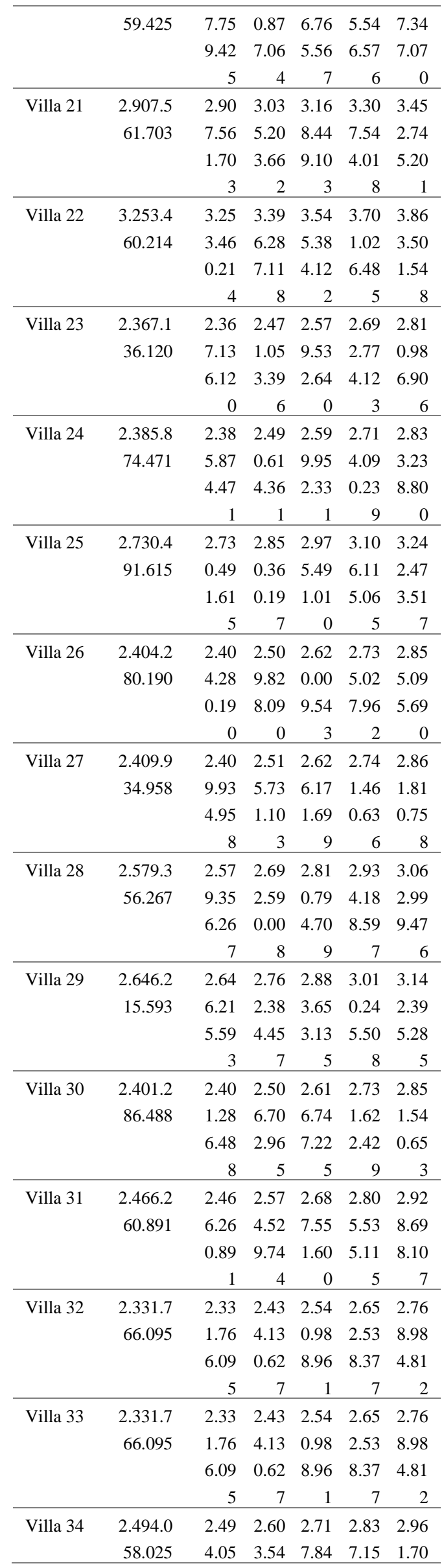

\begin{tabular}{lrrrrrr}
\hline & & 8.02 & 7.17 & 2.89 & 6.19 & 7.35 \\
& & 5 & 3 & 4 & 7 & 4 \\
\hline Villa 35 & 2.331 .7 & 2.33 & 2.43 & 2.54 & 2.65 & 2.76 \\
& 66.095 & 1.76 & 4.13 & 0.98 & 2.53 & 8.98 \\
& & 6.09 & 0.62 & 8.96 & 8.37 & 4.81 \\
& & 5 & 7 & 1 & 7 & 2 \\
\hline Villa 36 & 2.331 .7 & 2.33 & 2.43 & 2.54 & 2.65 & 2.76 \\
& 66.095 & 1.76 & 4.13 & 0.98 & 2.53 & 8.98 \\
& & 6.09 & 0.62 & 8.96 & 8.37 & 4.81 \\
& & 5 & 7 & 1 & 7 & 2 \\
\hline Villa 37 & 2.650 .7 & 2.65 & 2.7 & 2.8 & 3.0 & 3.1 \\
& 70.463 & 0.77 & 67. & 88. & 15. & 47. \\
& & 0.46 & 13 & 61 & 42 & 80 \\
& & 3 & 9.2 & 6.7 & 6.9 & 4.2 \\
& & & 86 & 01 & 74 & 18 \\
\hline
\end{tabular}

Tabel 24. Proyeksi Rencana Penjualan Unit Villatel Tahap 2

\begin{tabular}{|c|c|c|c|c|c|c|}
\hline \multirow[t]{3}{*}{ Villatel } & \multirow[t]{3}{*}{ Tipe } & \multicolumn{5}{|c|}{ Year } \\
\hline & & 1 & 2 & 3 & 4 & 5 \\
\hline & & \multicolumn{5}{|c|}{$4,39 \%$} \\
\hline & A1 & - & - & - & - & - \\
\hline & A2 & - & - & - & - & - \\
\hline & $\mathrm{A} 3$ & 1 & - & - & - & - \\
\hline & A4 & - & - & - & - & - \\
\hline & A5 & - & - & - & - & - \\
\hline & A6 & - & 1 & - & - & - \\
\hline & A7 & - & 1 & - & - & - \\
\hline & A8 & - & - & - & - & - \\
\hline & A9 & - & - & 1 & - & - \\
\hline & A10 & - & - & 1 & - & - \\
\hline & A11 & - & - & 1 & - & - \\
\hline & A12 & - & 1 & - & - & - \\
\hline & A15 & - & - & - & 1 & - \\
\hline & A16 & - & 1 & - & - & - \\
\hline & A17 & - & 1 & - & - & - \\
\hline & B1 & 1 & & - & - & - \\
\hline & B2 & - & - & - & 1 & - \\
\hline & B3 & 1 & - & - & - & - \\
\hline & B5 & - & - & - & - & 1 \\
\hline & B6 & 1 & - & - & - & - \\
\hline & $\mathrm{C} 1$ & - & - & - & - & - \\
\hline & $\mathrm{C} 2$ & - & - & - & 1 & - \\
\hline & $\mathrm{C} 3$ & 1 & - & - & - & - \\
\hline & $\mathrm{C} 5$ & -- & 1 & - & - & - \\
\hline & C6 & 1 & - & - & - & - \\
\hline & $\mathrm{C} 7$ & - & - & - & - & - \\
\hline & $\mathrm{C} 8$ & 1 & - & - & - & - \\
\hline & C9 & - & - & - & - & - \\
\hline & $\mathrm{C} 10$ & - & - & - & - & 1 \\
\hline & $\mathrm{C} 11$ & - & - & - & - & 1 \\
\hline & $\mathrm{C} 12$ & - & 1 & & - & - \\
\hline & $\mathrm{C} 15$ & - & - & 1 & - & - \\
\hline
\end{tabular}




\begin{tabular}{|c|c|c|c|c|c|c|}
\hline & $\mathrm{C} 16$ & - & - & 1 & - & - \\
\hline & $\mathrm{C} 17$ & - & - & - & 1 & - \\
\hline & $\mathrm{C} 18$ & - & - & - & 1 & - \\
\hline & C19 & 1 & - & - & - & - \\
\hline & $\mathrm{C} 20$ & - & - & - & - & 1 \\
\hline & $\mathrm{C} 21$ & - & - & - & - & - \\
\hline & $\mathrm{C} 22$ & - & 1 & - & - & - \\
\hline & $\mathrm{C} 23$ & - & - & - & - & 1 \\
\hline & D1 & - & - & - & - & - \\
\hline & D2 & - & - & - & - & 1 \\
\hline & D3 & - & - & 1 & - & - \\
\hline & D5 & - & - & 1 & - & - \\
\hline & D6 & - & - & - & - & - \\
\hline & D7 & - & - & - & 1 & - \\
\hline & D8 & - & - & - & 1 & - \\
\hline & D9 & - & - & - & - & - \\
\hline Jumlah Villa & atel & 8 & 8 & 8 & 7 & 6 \\
\hline
\end{tabular}

Tabel 25. Effective Gross Income (EGI)

Proyeksi Penjualan Unit Villatel Tahap 2

\begin{tabular}{|c|c|c|c|c|c|c|}
\hline \multirow[t]{3}{*}{ Villatel } & \multirow[t]{3}{*}{ Tipe } & \multicolumn{5}{|c|}{ Year } \\
\hline & & 1 & 2 & 3 & 4 & 5 \\
\hline & & \multicolumn{5}{|c|}{$4,39 \%$} \\
\hline & $\mathrm{A} 1$ & - & - & - & - & - \\
\hline & $\mathrm{A} 2$ & - & - & - & - & - \\
\hline & \multirow[t]{4}{*}{ A3 } & 2.05 & - & - & - & - \\
\hline & & 8.68 & & & & \\
\hline & & 1.11 & & & & \\
\hline & & 3 & & & & \\
\hline & A5 & - & - & - & - & - \\
\hline & \multirow[t]{5}{*}{ A6 } & - & 2.1 & - & - & - \\
\hline & & & 99. & & & \\
\hline & & & 98 & & & \\
\hline & & & 5.1 & & & \\
\hline & & & 71 & & & \\
\hline & \multirow[t]{5}{*}{ A7 } & - & 2.1 & - & - & - \\
\hline & & & 79. & & & \\
\hline & & & 96 & & & \\
\hline & & & 1.2 & & & \\
\hline & & & 24 & & & \\
\hline & A8 & - & - & - & - & - \\
\hline & \multirow[t]{5}{*}{ A9 } & - & - & 2.5 & - & - \\
\hline & & & & 40. & & \\
\hline & & & & 98 & & \\
\hline & & & & 8.9 & & \\
\hline & & & & 61 & & \\
\hline & \multirow[t]{5}{*}{ A10 } & - & - & 2.5 & - & - \\
\hline & & & & 40. & & \\
\hline & & & & 98 & & \\
\hline & & & & 8.9 & & \\
\hline & & & & 61 & & \\
\hline & A11 & - & - & 2.5 & - & - \\
\hline
\end{tabular}

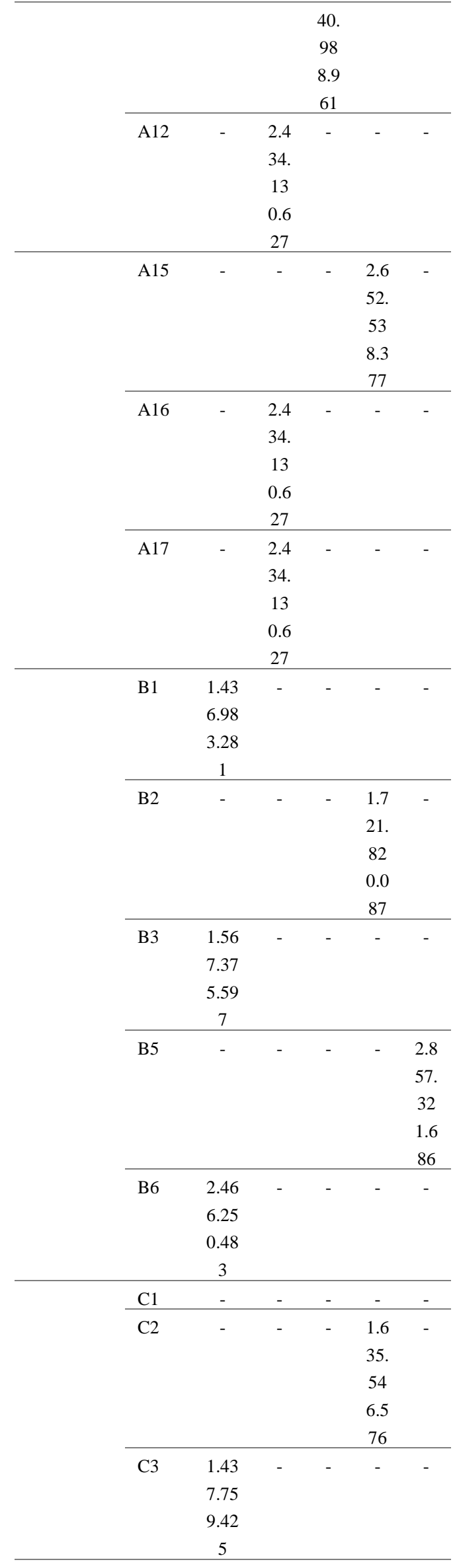

175 
Tegar Wibowo, Ida Ayu Ari Anggreni, Analisis Penilaian...

\begin{tabular}{|c|c|c|c|c|c|}
\hline C5 & - & $\begin{array}{c}1.5 \\
00 . \\
87 \\
7.0 \\
64\end{array}$ & - & - & - \\
\hline C6 & $\begin{array}{c}1.43 \\
7.75 \\
9.42 \\
5\end{array}$ & - & - & - & - \\
\hline C7 & - & - & - & - & - \\
\hline C8 & $\begin{array}{c}1.43 \\
7.75 \\
9.42 \\
5\end{array}$ & - & - & - & - \\
\hline $\begin{array}{l}\text { C9 } \\
\text { C10 }\end{array}$ & - & - & - & - & $\begin{array}{c}- \\
3.4 \\
52 . \\
74 \\
5.2 \\
01\end{array}$ \\
\hline C11 & - & - & - & - & $\begin{array}{c}3.8 \\
63 . \\
50 \\
1.5 \\
48 \\
\end{array}$ \\
\hline $\mathrm{C} 12$ & - & $\begin{array}{l}2.4 \\
71 . \\
05 \\
3.3 \\
96\end{array}$ & - & - & - \\
\hline C15 & - & - & $\begin{array}{l}2.5 \\
99 . \\
95 \\
2.3 \\
31 \\
\end{array}$ & - & - \\
\hline C16 & - & - & $\begin{array}{c}2.9 \\
75 . \\
49 \\
1.0 \\
10 \\
\end{array}$ & - & - \\
\hline C17 & - & - & - & $\begin{array}{l}2.7 \\
35 . \\
02 \\
7.9 \\
62 \\
\end{array}$ & - \\
\hline C18 & - & - & - & $\begin{array}{l}2.7 \\
41 . \\
46 \\
0.6 \\
36\end{array}$ & - \\
\hline C19 & $\begin{array}{c}2.57 \\
9.35 \\
6.26 \\
7\end{array}$ & - & - & - & - \\
\hline $\mathrm{C} 20$ & - & - & - & - & $\begin{array}{l}3.1 \\
42 . \\
39\end{array}$ \\
\hline
\end{tabular}

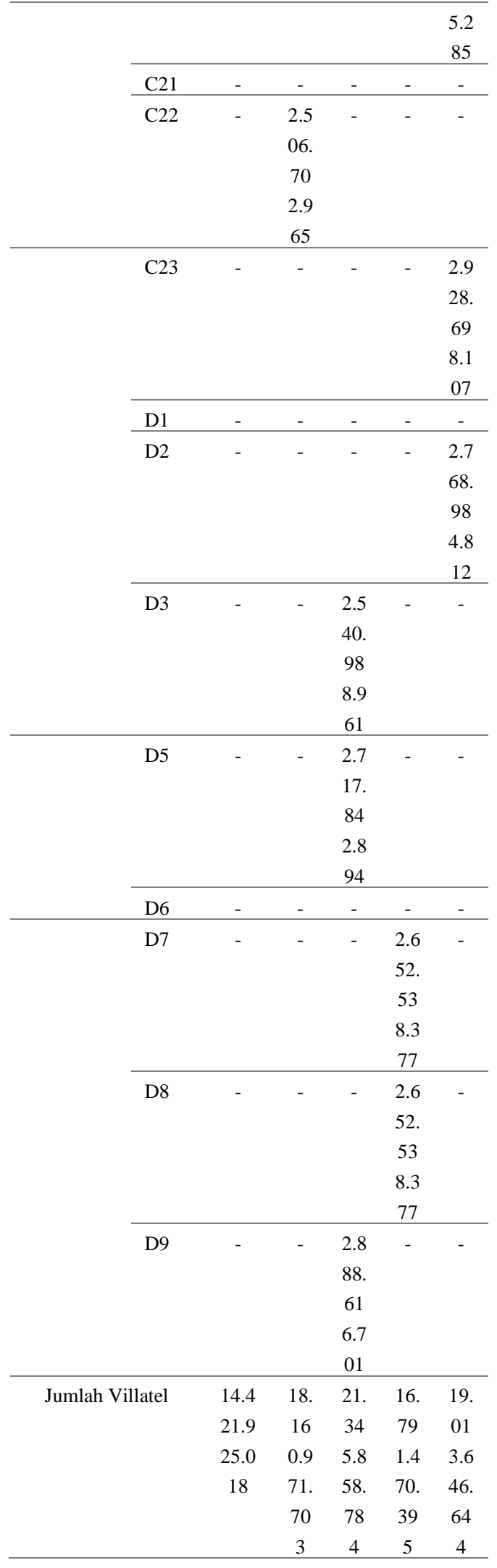

Tabel 26. Biaya Pengembangan Dan Biaya Operasional Unit Villatel Tahap 2 
POLITEKNOLOGI VOL. 20 NO. 2 MEI 2021

\begin{tabular}{llccccc}
\hline \multicolumn{1}{c}{ Biaya } & \multirow{2}{*}{$\begin{array}{c}\text { Cost to } \\
\text { Pengembang }\end{array}$} \\
\cline { 3 - 7 } \multicolumn{1}{c}{ complete } & & $\mathbf{1}$ & $\mathbf{2}$ & $\mathbf{3}$ & $\mathbf{4}$ & $\mathbf{5}$ \\
\hline Biaya Perizinan & - & - & & - & \\
\hline Biaya & 54.000 .000 & 54.0 & & - & \\
Perencanaan & & 00.0 & & & \\
& & 00 & & & \\
\hline Pematangan & 149.972 .16 & 74.9 & 74. & - & \\
Lahan & 0 & 86.0 & 98 & & \\
& & 80 & 6.0 & & \\
& & & 80 & & \\
\hline
\end{tabular}

\begin{tabular}{|c|c|c|c|c|c|c|}
\hline & & 500 & 19. & 17. & 29. & 72. \\
\hline & & & 43 & 17 & 40 & 93 \\
\hline & & & 4 & 6 & 8 & 3 \\
\hline Biaya Sosial, & $0,05 \%$ & 7.21 & 9.0 & 10. & 8.3 & 9.5 \\
\hline dll & & 0.96 & 80. & 67 & 95. & 06. \\
\hline & & 3 & 43 & 2.9 & 73 & 82 \\
\hline & & & 6 & 29 & 5 & 3 \\
\hline Keuntungan & $10 \%$ & 1.44 & 1.8 & 2.1 & 1.6 & 1.9 \\
\hline Developer & & 2.19 & 16. & 34. & 79. & 01. \\
\hline & & 2.50 & 09 & 58 & 14 & 36 \\
\hline & & 2 & 7.1 & 5.8 & 7.0 & 4.6 \\
\hline & & & 70 & 78 & 39 & 64 \\
\hline Total & & 11.3 & 12. & 4.2 & 3.3 & 3.8 \\
\hline Pengeluaran & & 78.4 & 07 & 79. & 66. & 12. \\
\hline & & 83.7 & 4.1 & 84 & 68 & 23 \\
\hline & & 96 & 62. & 4.6 & 9.8 & 6.1 \\
\hline & & & 65 & 86 & 13 & 51 \\
\hline & & & 6 & & & \\
\hline Pendapatan & & 3.04 & 6.0 & 17. & 13. & 15. \\
\hline Bersih & & 3.44 & 86. & 06 & 42 & 20 \\
\hline & & 1.22 & 80 & 6.0 & 4.7 & 1.4 \\
\hline & & 1 & 9.0 & 14. & 80. & 10. \\
\hline & & & 45 & 09 & 57 & 48 \\
\hline & & & & 6 & 8 & 8 \\
\hline Tingkat & & 11 & 11, & 11, & 11, & 11 , \\
\hline Diskonto & & $86 \%$ & 86 & 86 & 86 & 86 \\
\hline & & & $\%$ & $\%$ & $\%$ & $\%$ \\
\hline & & 0,89 & 0,7 & 0,7 & 0,6 & 0,5 \\
\hline & & 40 & 99 & 14 & 88 & 71 \\
\hline & & & 2 & 5 & & 1 \\
\hline Nilai & 37.035 .668 & 2.72 & 4.8 & 12. & 8.5 & 8.6 \\
\hline Properti & 795 & 0.82 & 64. & 19 & 75. & 80. \\
\hline & & 7.58 & 76 & 3.8 & 34 & 89 \\
\hline & & 7 & 5.2 & 37. & 5.2 & 3.0 \\
\hline & & & 15 & 73 & 00 & 54 \\
\hline & & & & 8 & & \\
\hline Pembulatan & $\begin{array}{l}37.035 .700 . \\
000\end{array}$ & & & & & \\
\hline
\end{tabular}

\section{Pek. Sal
Resapan}

Pek Jalan, dil

$348.777 .00 \quad 174 . \quad 17 \quad-$

388. 4.3

50088.

50

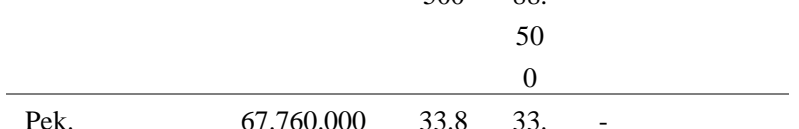

$\begin{array}{lcccc}\text { Pek. } & 67.760 .000 & 33.8 & 33 . & - \\ \text { Penerangan } & & 80.0 & 88 & \\ & & 00 & 0.0 & \end{array}$

\begin{tabular}{lllll} 
& & & 00 & \\
\hline Pek. Hard \& & 215.000 .00 & 107. & 10 & - \\
Soft Landscape & 0 & 525. & 7.5 &
\end{tabular}

\begin{tabular}{llccl} 
& & & & \\
& & 00 & \\
& & & 0 & \\
\hline Biaya & 14.608 .754$. & 7.30 & 7.3 & - \\
Konstruksi & 000 & 1.87 & 01. & \\
Bangunan & & 7.00 & 87 & \\
& & 0 & 7.0 & \\
& & & 00 & \\
\hline Kolam Renang & 1.480 .462 .5 & 740. & 74 & - \\
Dalam Unit & 00 & 231. & 0.2 & \\
& & 250 & 31. & \\
& & & 25 & \\
& & & 0 & \\
\hline Total & 16.919 .757$. & & & \\
& 660 & & & \\
\hline
\end{tabular}

Biaya

\begin{tabular}{lcccccc} 
Operasional & & & & & & \\
\hline Payroll & $5 \%$ & 721. & 90 & 1.0 & 83 & 95 \\
General, & & 096. & 8.0 & 67. & 9.5 & 0.6 \\
Overhead \& & & 251 & 48. & 29 & 73. & 82. \\
Adm & & & 58 & 2.9 & 52 & 23 \\
& & & 5 & 39 & 0 & 2 \\
\hline Marketing Fee & $3 \%$ & 432. & 54 & 64 & 50 & 57 \\
& & 657. & 4.8 & 0.3 & 3.7 & 0.4 \\
& & 751 & 29. & 75. & 44. & 09. \\
& & & 15 & 76 & 11 & 39 \\
& & & 1 & 3 & 2 & 9 \\
\hline Advertising & $2 \%$ & 288. & 36 & 42 & 33 & 38 \\
& & 438. & 3.2 & 6.9 & 5.8 & 0.2 \\
\hline
\end{tabular}
000

Tabel 27. Nilai Pasar X

\begin{tabular}{|c|c|c|}
\hline No & Uraian & $\begin{array}{l}\text { Nilai Pasar } \\
\quad(\text { Rp) }\end{array}$ \\
\hline I & Tahap I & \\
\hline 1 & X Tower & 105.277 .600 .000 \\
\hline \multirow[t]{2}{*}{2} & Bangunan & \\
\hline & -Marketing Gallery & 1.937.026.372 \\
\hline
\end{tabular}




\begin{tabular}{llr}
\hline 3 & Sarana Pelengkap & 141.898 .843 \\
\hline & & \\
\hline 4 & Inventaris Kantor & 557.506 .559 \\
\hline & & 108.914 .031 .774 \\
\hline & SUB TOTAL \\
\hline & & \\
\hline II & Tahap II & 37.035 .668 .795 \\
\hline 1 & Villatel Tahap 2 & 37.035 .668 .795 \\
\hline & SUB TOTAL \\
\hline & & 145.949 .700 .569 \\
\hline & JUMLAH & 145.950 .000 .000 \\
\hline
\end{tabular}

Setelah dilakukan perhitungan secara menyeluruh tentang penilaian $\mathrm{X}$ didapatkan nilai untuk tahap satu adalah sebesar Rp108 914031774 (Seratus Delapan Milyar Sembilan Ratus Empat Belas Juta Tiga Puluh Satu Ribu Tujuh Ratus Tujuh Puluh Empat Rupiah), sedangkan untuk yang tahap dua didapatkan nilai Rp37 035 668795 (Tiga Puluh Tujuh Milyar Tiga Puluh Lima Juta Enam Ratus Enam Puluh Delapan Ribu Tujuh Ratus Sembilan Puluh Lima Rupiah), untuk mendapatkan nilai pasar maka seluruhnya ditotal sehingga mendapatkan nilai sebesar Rp145 949 700569 atau bisa dibulatkan sebesar Rp145 950000000 (Seratus Empat Puluh Lima Milyar Sembilan Ratus Lima Puluh Juta Rupiah).

\subsection{Nilai Likuidasi $X$}

Nilai Likuidasi atau nilai jual paksa adalah nilai dimana jika sebuah instansi ataupun perorangan yang berhutang terhadap bank ataupun peminjam modal tidak mampu membayar sesuai dengan kesepakatan yang sudah disepakati maka bangunan yang dijadikan agunan akan ditarik oleh peminjam modal dan akan dijual secara paksa sebesar $70 \%$ dari nilai pasar. Berarti dalam hal ini nilai likuidasi X adalah sebesar Rp102 165 000000 (Seratus Dua Milyar Seratus Enam Puluh Lima Juta Rupiah).

\section{DAFTAR PUSTAKA}

[1] J. B. T. Iii- and E. J. Barat, "Pertumbuhan Ekonomi," no. 60, pp. 1-12, 2019.

[2] P. Asli, D. Pad, R. E. Rianto, P. P. E. F. G. Mada, and U. G. Mada, "Estimasi Nilai Sewa Tanah Dan Bangunan PT. KA (Persero) DAOP VI Guna Peningkatan Pemerintah Daerah Istimewa Yogyakarta," vol. 15, no. 3, pp. 332-338, 2000.

[3] E. Widayanti, P. Studi, M. Akuntansi, F. Ekonomi, and U. S. Maret, "Optimalisasi Pemanfaatan Aset Tetap (Studi Kasus di Kabupaten Sragen) untuk Memenuhi Sebagian Persyaratan Mencapai Derajat Magister Program Studi Magister Akuntansi Minat Utama: Akuntansi Sektor Publik (Studi Kasus di Kabupaten Sragen)," 2010.

[4] F. Ekonomika, D. A. N. Bisnis, and U. G. Mada, "Estimasi Nilai Hotel Terkait Build Operate and Transfer (BOT)," 2011.

[5] B. Sujono, "Penilaian Asset Dalam Sektor Properti," pp. 37-40.

[6] S. Ramisda, "Analisa Nilai Pasar Hotel Inna Simpang," vol. 1, no. 1, 2012.

[7] K. Gedung and B. Kota, "Evaluasi dan Penilaian Aset Bangunan (Studi Evaluasi dan Penilaian Aset Bangunan)" 2017.

[8] T. Nilai et al., "(Studi Pada Perusahaan Sektor Property dan Real Estate Di Bursa Efek Indonesia Periode 2011-2014)," no. October, 2017. 